\title{
MAFIC-SILICIC MAGMA INTERACTION IN THE LAYERED 1.87 GA SOUKKIO COMPLEX IN MÄNTSÄLÄ, SOUTHERN FINLAND
}

\author{
T.T. EEROLA
}

EEROLA, T.T. 2002. Mafic-silicic magma interaction in the layered $1.87 \mathrm{Ga}$ Soukkio Complex in Mäntsälä, southern Finland. Bulletin of the Geological Society of Finland 74, Parts 1-2, 159-183.

The Svecofennian layered Soukkio Complex (1.87 Ga) in Mäntsälä, southern Finland, consists of layered tholeiitic gabbro and porphyritic calc-alkaline monzonite, quartz monzonite and granite, mingled together. The gabbro belongs to a group of ten mafic-ultramafic intrusions of Mäntsälä, part of the $150 \mathrm{~km}$ long and 20 km wide, linear, E-W trending Hyvinkää-Mäntsälä Gabbroic Belt (HMGB), representing syn-collisional magmatism.

Structures and textures related to magma mingling and mixing occur in a 1$2 \mathrm{~km}$ wide zone around Lake Kilpijärvi, located at the center of the Soukkio Complex. The complex is compositionally stratified and consists of four zones: its base, found at the Western Zone, is a dynamically layered gabbro. The following tonalite is probably a result of magma mixing. Felsic amoeboid layers and pipes, alternating with or cutting the fine-grained gabbro in the CentralWestern Zone, resemble those of mafic-silicic layered intrusions in general. Mafic magmatic enclaves (MMEs) and pillows form the South-Central Zone and disrupted synplutonic mafic dykes or sheets intruded the granite in the Eastern Zone.

The MMEs and disrupted synplutonic mafic dykes or sheets show cuspate and chilled margins against the felsic host, quartz ocelli, corroded K-feldspar xenocrysts with or without plagioclase mantles, and acicular apatite, all typical features of magma mingling and mixing. Mixing is suggested by intermediate composition of MMEs between granitoid and gabbro, as well as by their partly linear trends in some Harker diagrams. REE composition of the MMEs is similar to that of the Soukkio Gabbro, as expected for granite hosted MMEs.

The model proposed for evolution of the Soukkio Complex involves intrusion of mafic magma into the crust, causing its partial melting. This generated granitic magma above the mafic chamber. Injections of mafic magma invaded the felsic chamber and those magmas interacted mainly by intermingling.

Mingling and mixing of contrasting magmas is also found elsewhere in the Mäntsälä region and $\mathrm{HMGB}$, suggesting a widespread synorogenic zone of coeval mafic-silicic plutonism and crust-mantle interaction during the Svecofennian Orogeny in Finland.

Key words: layered intrusions, gabbros, monzonites, granites, quartz monzonite, textures, inclusions, geochemistry, magmatism, mixing, Paleoproterozoic, Soukkio, Mäntsälä, Finland

Toni T. Eerola: Department of Geosciences, Federal University of Santa Catarina, Campus Universitário, B. Trindade, 88040-970 Florianópolis, SC, Brazil. E-mail: teerola@cfh.ufsc.br 


\section{INTRODUCTION}

Intrusion of basaltic magma into the crust is often intimately associated with the forming of silicic magmas by crustal melting, and during this process the magmas can act together and be mingled and mixed (Hildreth 1981, Huppert \& Sparks 1988, Andersson 1991, Hall 1996). This interaction of coexisting mafic and silicic magmas is a common, widely accepted, important and complex petrologic process, which occurs in rocks of all ages and all geotectonic environments (Didier \& Barbarin 1991a, Pitcher 1993, Hall 1996).

Previously, magma mingling/mixing features, such as K-feldspar phenocrysts in mafic enclaves, have been commonly considered to represent granitization of gabbroic xenoliths by potassium metasomatism (see discussions and references in Vernon 1986, 1996, Pitcher 1993, Hall 1996, Sylvester 1998). This is the case also for the Svecofennian Soukkio Gabbro in Mäntsälä, southern Fin- land (Härme 1958, 1978), part of the layered Soukkio Complex (Eerola \& Törnroos 2000, Figs. 1 and 2). However, the granitization hypothesis is unable to explain features found in the complex. Moreover, the experimental work by Tuttle and Bowen (1958) showed that granitization by metasomatism is untenable (Krauskopf 1982, p. 327) and it has been generally abandoned (Hall 1996, p. 334). Based on current literature, these features were recently interpreted to represent coeval interaction of compositionally contrasting magmas (Eerola \& Haapala 2000, Eerola \& Törnroos 2000, Eerola et al. 2000).

This paper describes in more detail the textures, structures, zonation and geochemistry of the Soukkio Complex that indicate operation of magma mingling and mixing processes. A model for evolution of the complex is also proposed.

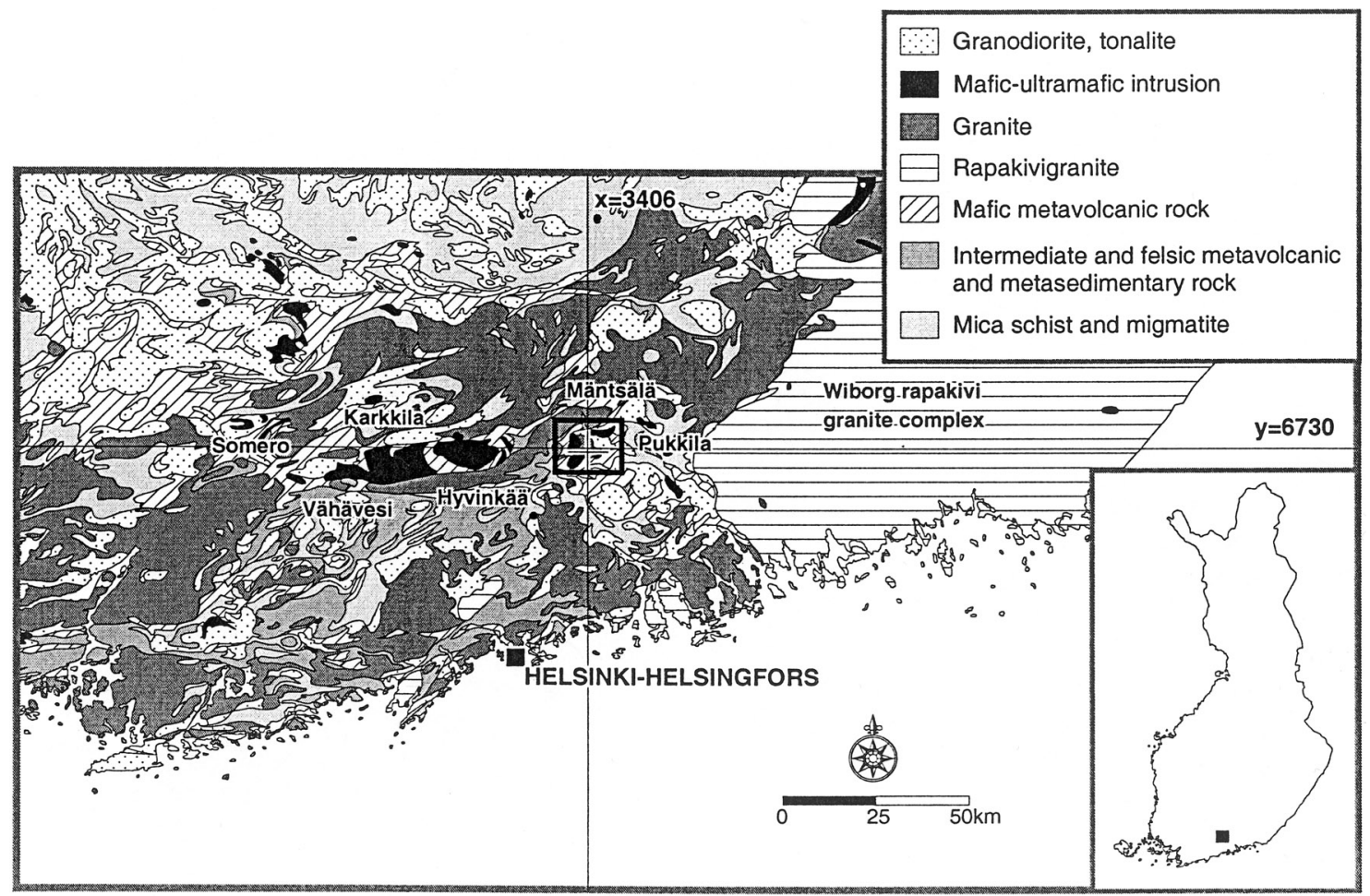

Fig. 1. Precambrian bedrock map of southern Finland (after Koistinen 1994), showing location of the Mäntsälä region. 


\section{MAGMA MINGLING AND MIXING: CHARACTERISTICS AND PROCESSES}

The best methods to detect magma mingling and mixing are careful field and microscopic observations (Nardi \& Lima 2000), because the structures related to this phenomenon are very characteristics. However, there is a great variation in shape and size, ranging from net-veined complexes to fine-scale streaky intermingling (Xu et a. 1999). The most typical features are mafic microgranular enclaves (Didier 1973), mafic microgranitoid enclaves (Vernon 1983) or mafic magmatic enclaves (Barbarin 1988), referred herewith as MMEs according to recommendation of Didier and Barbarin (1991b), and synplutonic dykes (see Pitcher 1991) in a more felsic host. MMEs are generally fine-grained blobs of mafic magma with chilled margins, apatite needles and zoned plagioclase, evidencing quenching of the MME against the felsic host due to great thermal contrast (Vernon 1983, 1984, 1986). Other typical textural features are K-feldspar ovoids with mantled rims of plagioclase and quartz surrounded by hornblenditic rim (quartz ocelli) in MMEs, suggesting mechanical mixture with the host (Blake et al. 1965, Vernon 1983, 1984, Pitcher 1993, Sylvester 1998, $\mathrm{Xu}$ et al. 1999). MMEs may have cuspate contacts, indicating their magmatic state, and as long as the viscosity of the MME is lower than the viscosity of the host, they are able to capture other enclaves and K-feldspar and quartz xenocrysts from the host (Vernon 1983, 1984). MMEs result from disintegration of mafic magma by felsic magma.

Synplutonic dykes are linear mafic bodies that intrude a more felsic host, which is crystallizing, and are commonly disrupted by flow of the visco-plastic host, resulting in aligned MMEs (e.g. Pitcher 1991, Mellqvist 1999).

Most of the models proposed to explain how the interaction of different magmas takes place in the plutonic environment involve intrusion of mafic magma into a silicic magma chamber (Blake et al. 1965, Vernon 1983, Huppert \& Sparks 1988, Lindberg \& Eklund 1988, Nironen \& Bateman 1989, Pitcher 1991, Michael 1991, Neves \& Vauchez 1995, Salonsaari 1995, Wiebe 1993,
1996, Hall 1996, Mellqvist 1999, Bergantz 2000, Preston 2001). However, the opposite could also be important and possible (Wiebe 1987a,b, Koyaguchi \& Blake 1991, Weinberg 1997).

High injection speed and turbulence of mafic magma and flow of the host favor their mixing (Campbell \& Turner 1989). Mixing is also favored if the volume of mafic magma is great and if it has low viscosity and compositional contrasts with the host - the contrary favors magma mingling (Koyaguchi \& Blake 1991). If mafic magma enters slowly into a felsic magma chamber, it flows on the floor and creates mafic-felsic layering (Campbell \& Turner 1989, Wiebe \& Snyder 1993, Snyder \& Tait 1995, Bergantz 2000), common in mafic silicic layered intrusions (Wiebe 1993a, 1996) or stratified composite intrusions (Wiebe \& Collins 1998). This favors magma mingling (Campbell \& Turner 1989) and consequent pillow formation by flow-front instability (Snyder \& Tait 1995). If these processes take place in a shallowlevel intrusion, magma mingling is more probable to occur because of faster cooling (Pitcher 1993, Hall 1996). In orogenic complexes, due to availability of major heat budget and a greater time span, magma mixing is generally preferred over mingling (Andersson 1991, O. Eklund, pers. comm. 2001). However, according to Wiebe (1991) and Hall (1996), a proof for extensive mixing with generation of voluminous intermediate magmas is difficult to find, and independent on tectonic environment, magma mingling is by far the most common expression of interaction of contrasting magmas.

\section{COEVAL CONTRASTING MAGMATISM IN THE SVECOFENNIAN OROGEN}

The interaction between mafic and silicic magmas occurred at all stages of the Svecofennian Orogeny in the Fennoscandian shield, having an important role in its crustal evolution (Andersson 1991). The phenomenon is recorded in the Finnish 1.91.87 Ga synorogenic complexes (Nironen 1989, Nironen \& Bateman 1989, Ehlers \& Lindroos 1990, Lahtinen 1994, 1996, Kärkkäinen \& Ap- 
pelqvist 1999, Rämö et al. 1999, Eerola et al. 2000, Nironen et al. 2000, Pääjärvi 2000), 1.83 Ga late-orogenic potassium granites (Lahtinen 1996, Rämö et al. 1999) and dykes (Rautiainen 2000), and $1.80 \mathrm{Ga}$ post-orogenic complexes (Lindberg \& Eklund 1988, Eklund et al. 1999, Väisänen et al. 2000). It was common also in the 1.65-1.54 Ga Finnish anorogenic rapakivi granites (e.g. Lindberg \& Eklund 1992, Salonsaari 1995, Rämö et al. 1999). According to R. Lahtinen (pers. comm. 1999), magma mingling and mixing were probably much more common during the Svecofennian Orogeny in Finland than what has been previously thought, but to date these occurrences have not received much attention. Indeed, there are only brief mentions and few detailed descriptions on these phenomena in the Finnish Svecofennian synorogenic complexes.

\section{GEOLOGICAL SETTING OF THE MÄNTSÄLÄ REGION}

\section{The Hyvinkää-Mäntsälä Gabbroic Belt}

The Mäntsälä region, located $50 \mathrm{~km} \mathrm{NE}$ from Helsinki (Fig. 1), belongs to the Häme Belt, an EW trending Svecofennian (1.9-1.87 Ga) volcanic-sedimentary belt (Hakkarainen 1994, Kähkönen et al. 1994, Tiainen \& Viita 1994). The belt is part of the Accretionary Arc Complex of Southern Finland (Rämö et al. 1999, Nironen et al. 2000). The volcanic rocks of the Häme Belt show island arc to within-plate signatures (Hakkarainen 1994, Lahtinen 1996).

The Mäntsälä gabbros are part of an E-W trending linear belt of mafic-ultramafic intrusions, which extends from Somero to Pukkila (Koistinen 1994, Fig. 1), and is known as the HyvinkääMäntsälä Gabbroic Belt (HMGB; Eerola et al. 2000, Raitala et al. 2000). The HMGB consists of several mafic-ultramafic intrusive associations, with coeval granitic magmatism. The gabbros of the HMGB have $\mathrm{U}-\mathrm{Pb}$ zircon ages of 1.88-1.87 $\mathrm{Ga}$ and $\varepsilon_{\mathrm{Nd}}$ values of +2 to +3 (Huhma 1986, Patchett \& Kouvo 1986). This records the existence of young lithospheric mantle formed from depleted mantle source under thin and immature crust during 1.91-1.89 Ga (Andersson 1991, Lahtinen 1994). The HMGB represents the voluminous syn-collisional magmatism at $1.88-1.87$ $\mathrm{Ga}$, which was a major new crust forming process (Lahtinen 1994, 1996). The abundant mantlederived magmatism could have been the result of lithospheric thickening, followed by upwelling of the thermal boundary and leading to magmatic underplating and high heat flow (ibid.). The consequent partial melting of the crust generated abundant felsic magma, which interacted with the mafic one. The linear trend of the HMGB intrusions may reflect extension and generation or reactivation of deep fractures and shear zones by which the mafic magma intruded at $1.88-1.87 \mathrm{Ga}$.

\section{Mafic-ultramafic intrusions in Mäntsälä}

The bedrock in Mäntsälä consists of SW-NE trending metavolcanic and -sedimentary rocks, mafic-ultramafic intrusions, and granitoids (Fig. 2 ). The mafic and felsic plutonic rocks are closely related and a granitoid batholith occupies the major part of the area. The mafic-ultramafic intrusions are located mostly at the edges of this batholith (Fig. 2). The regional metamorphism reached upper amphibolite facies (Kähkönen et al. 1994). The Mäntsälä mafic-ultramafic association consists of ten subcircular to elongate layered bodies of gabbros, pyroxenites, and anorthosites (Kaitaro 1956, Härme 1978, Eerola 2000). The surface area of the intrusions varies between 0.5 and 25 $\mathrm{km}^{2}$. The major gabbroic intrusions of the region are the Hirvihaara, Soukkio and Pitkäjärvi Gabbros (Fig. 2). Based on dating on the Soukkio Gabbro (Huhma 1986), the Mäntsälä gabbros are ca. $1870 \mathrm{Ma}$ in age.

Mafic volcanic rocks, especially agglomerates, surround most of the gabbro bodies. This has been interpreted to support comagmatic relationship for these rocks and to indicate that the gabbros represent magma chambers of volcanoes (Härme 1978). In fact, the metavolcanic rocks, mafic intrusions, and synkinematic granitoids are roughly coeval (Patchett \& Kouvo 1986) and closely associated in many Svecofennian plutons (Nurmi \& Haapala 1986, Lahtinen 1996). Granitic clasts 


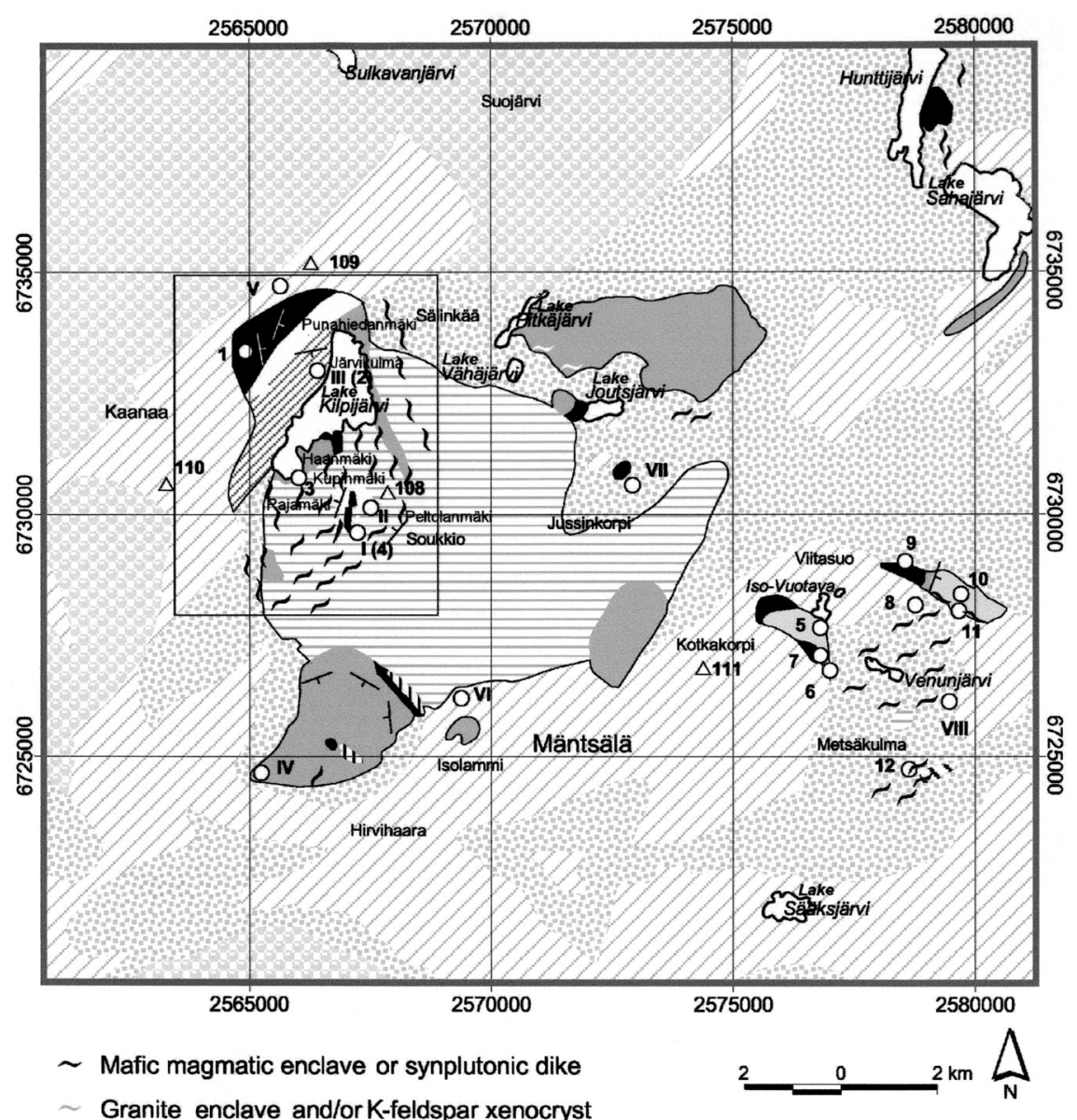

$\sim$ Granite enclave and/or K-feldspar xenocryst

$\triangle$ Protected educational bedrock site of Province of Southern Finland (Kananoja \& Grönholm 1993)

- I-VIII Bedrock outcrops exposed by local inhabitants (Eerola 2000)

I-12 Excursion outcrops related to Mäntsälä gabbros (Eerola 2000)

\section{Gabbroic complexes}

$\square$ Monzonite - Granite
$\square$ Anorthosite
$\square$ Gabbro and diorite
WW/ Fine-grained gabbro, hornblendite and
monzonite layers
$\square$ Tonalite-trondhjemite
Cumulate and hornblendite

\section{Country rocks}

IIII Pegmatite

$\square$ Potassium granite

N Syenite

Granodiorite and granite-gneiss

Basic and intermediate volcanic, amphibolite and other supracrustal rock
Fig. 2. Precambrian bedrock map of the Mäntsälä region (after Kaitaro 1956). The Soukkio Complex is framed. Site 1 - Sarkasuo; Site 2 - Järvikulma; Site 3 Kupinmäki; Site 4 Soukkio. found by the author in the volcanic-sedimentary succession at the eastern side of the Mäntsälä region suggest rapid exhumation of granitoids or existence of older crust there.

\section{The Soukkio Complex}

The Soukkio Complex is composed of a mafic part, the Soukkio Gabbro, and a felsic part, the 


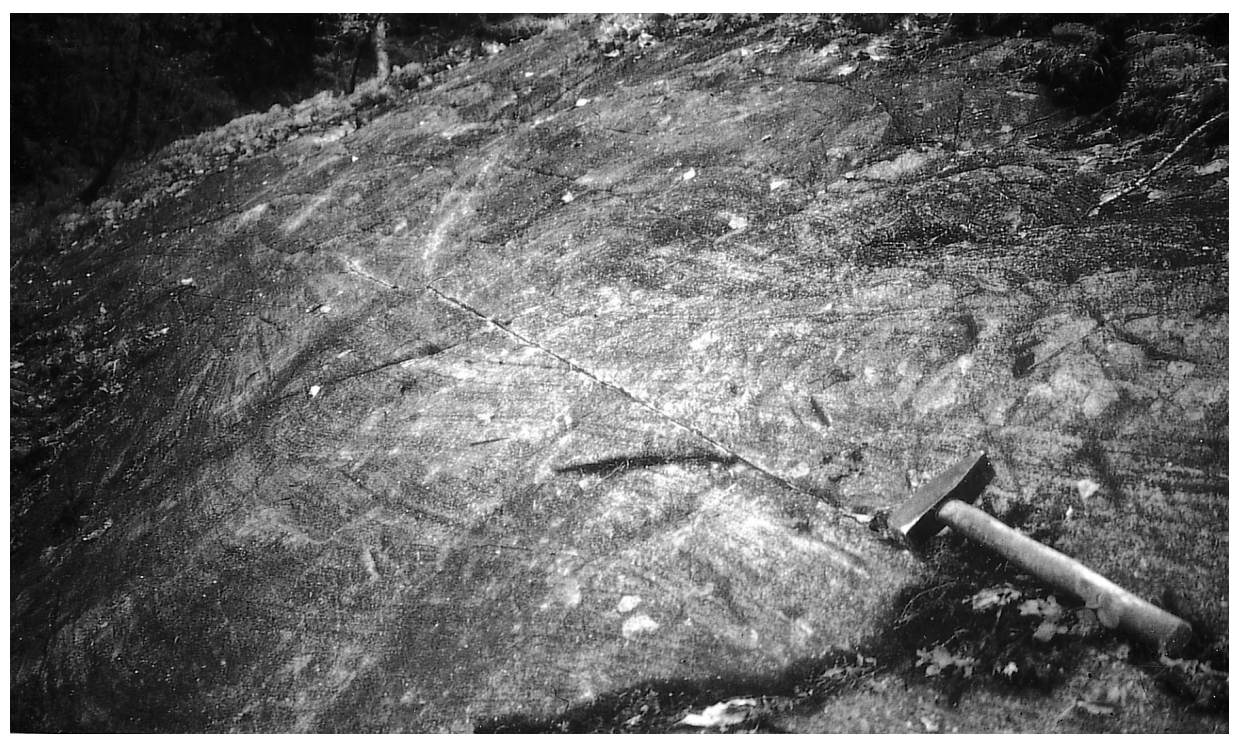

Fig. 3. Dynamic layering in the gabbroic Layered Series, western border of the Soukkio Complex (Site 1). Photo by the author.

Soukkio Granitoid, which mainly surrounds the gabbro.

\section{The Soukkio Gabbro}

The Soukkio Gabbro, at and around Lake Kilpijärvi (Fig. 2, Kaitaro 1956), is distinguished as a strong positive anomaly on aeromagnetic and gravity maps (Eerola \& Ajlani 2000), which is a typical feature for complexes with mafic-felsic magma interaction (Andersson 1991, Hall 1996). It is a plate-like sill or sheet of layered hornblende gabbro, inclined gently toward the east. Minor peridotites and anorthosites are found in the lower zone in the western part.

The main minerals of the Soukkio Gabbro are hornblende, plagioclase, titanite, apatite, and oxides. Layering can be best observed at the western margin at Sarkasuo (Site 1 in Fig. 2), where the gabbro shows cross-stratification, parallel bedding, slumping, trough and cut-and-fill structures, represented by alternating layers of anorthosites and horblendites (former pyroxenites, Fig. 3, see also Eerola 2000, Eerola \& Törnroos 2000). These structures suggest dynamic layering formed by collapse of partially crystallized cumulates and their flow on the magma chamber floor as density currents (see Wager \& Brown 1967, McBirney $\&$ Nicolas 1997). Massive and layered mafic-ultramafic cumulates with patches of anorthosite overlay this sequence. These patches represent less dense diapirs intruded from the layers below (cf. Wager \& Brown 1967).

Cumulates are also well exposed on the eastern side of Lake Kilpijärvi and are intruded by late-magmatic gabbroic pegmatoids. These features are similar to those found in the Skaergaard Intrusion and provide evidence for well-developed differentiation and crystal fractionation (Wager \& Brown 1967, Larsen \& Brooks 1994). In addition, the gabbro is characterized by strong variations of crystal size and is intruded by mafic dykes and granitic pegmatites.

\section{The Soukkio Granitoid}

The Soukkio Granitoid is mainly a pink, coarsegrained, porphyritic calc-alkaline and peraluminous granite, locally monzonitic in composition. The main minerals are microcline, hornblende, plagioclase, biotite, and quartz, with zircon, titanite and opaque phases as accesso- 
ry minerals. Granophyric and rapakivi textures are common, as well as oval K-feldspar, especially where there are MMEs. The MMEs and $\mathrm{K}$-feldspar have magmatic orientation parallel to the margins of the complex, but a part of orientation, indicated by K-feldspar augens and local gneissic fabric, was caused by shearing.

Kaitaro (1956) recognized the diverse nature of the Soukkio Granitoid, compared to the lateorogenic potassium granite in the Mäntsälä region. Late-orogenic potassium granite $(\sim 1.83$ $\mathrm{Ga}$, Ehlers et al. 1993) has been thought to have caused granitization of the solid Soukkio Gabbro by potassium metasomatism (Härme 1958, 1978). However, this granite intruded the gabbro and granitoid (Härme 1978) in the form of pegmatites and did not have interaction with or effect on the gabbro (Eerola et al. 2000). Instead, the Soukkio Granitoid shows clear indications of magma interaction with the gabbro, suggesting a similar age (Eerola \& Törnroos 2000, Eerola et al. 2000).

\section{STRUCTURES AND TEXTURES SUGGESTING MAGMA MINGLING}

Structures and textures suggesting interaction of compositionally contrasting magmas are common in a NE-SW trending, 1-2 km wide area surround- ing Lake Kilpijärvi. A NW-SW profile through the complex is divided into four zones, the Western Zone, Central-Western Zone, South-Central Zone and Eastern Zone. These zones are described below and their characteristics are summarized in Table 1.

\section{Western Zone: a layered gabbro}

The Western Zone represents basal cumulate. The previously described Sarkasuo area equals the Layered Series of Wiebe (1987a,b). The Punahiedanmäki area with tonalites-granodiorites, probably a result of magma mixing, follows it upward in the stratigraphy of the complex (Fig. 2). These felsic rocks carry a polygenic enclave swarm, including MMEs, and stratified volcanic and pelitic xenoliths.

\section{Central-Western Zone: mafic and felsic layering}

The Järvikulma region (Site 2, Fig. 2) shows layering of felsic and mafic rocks, and equals the Hybrid Series of Wiebe (1987a,b). The base of the exposed succession is characterized by alternation of ultramafic, fine-grained mafic, and monzonitic layers. Features suggesting magma mingling and mixing are visible at the contacts as K-feldspar xenocrysts in the hornblendite, and as horn-

Table 1. Summary of zonation of magmatic structures and their interpretation in the Soukkio Complex.

\begin{tabular}{|c|c|c|}
\hline Zone and Site & Main magmatic structures & Interpretation \\
\hline $\begin{array}{l}\text { Western Zone } \\
\text { Layered Series } \\
\text { - Gabbro (Site 1) }\end{array}$ & $\begin{array}{l}\text { Cross-stratification, slumping, } \\
\text { pot-holes, through structures }\end{array}$ & $\begin{array}{l}\text { Dynamic layering on the mafic magma } \\
\text { chamber floor }\end{array}$ \\
\hline $\begin{array}{l}\text { Central-Western } \\
\text { Zone Hybrid Series- } \\
\text { Gabbro and Granite } \\
\text { (Site 2) }\end{array}$ & $\begin{array}{l}\text { Fine-grained mafic and ribbon-like } \\
\text { felsic layers and dykes, flame and } \\
\text { load-cast structures in chilled contacts }\end{array}$ & $\begin{array}{l}\text { Interlayering of felsic and mafic magmas } \\
\text { by intrusion of mafic magma in a silicic } \\
\text { magma chamber }\end{array}$ \\
\hline
\end{tabular}

\begin{tabular}{lll}
\hline South-Central Zone & Mafic pillows (MMEs), double enclaves, Disruption of mafic magma by felsic \\
Gabbro and Granite & K-feldspar xenocrysts (ovoids) with & magma \\
(Site 3) & rapakivi textures &
\end{tabular}

Eastern Zone

Granite and Gabbro

(Site 4)

$\begin{array}{ll}\begin{array}{l}\text { Elongated sheet-like MMEs in granite, } \\ \text { rapakivi texture, quartz ocelli }\end{array} & \begin{array}{l}\text { Intrusion of mafic magma in flowing } \\ \text { granitic crystal mush }\end{array}\end{array}$




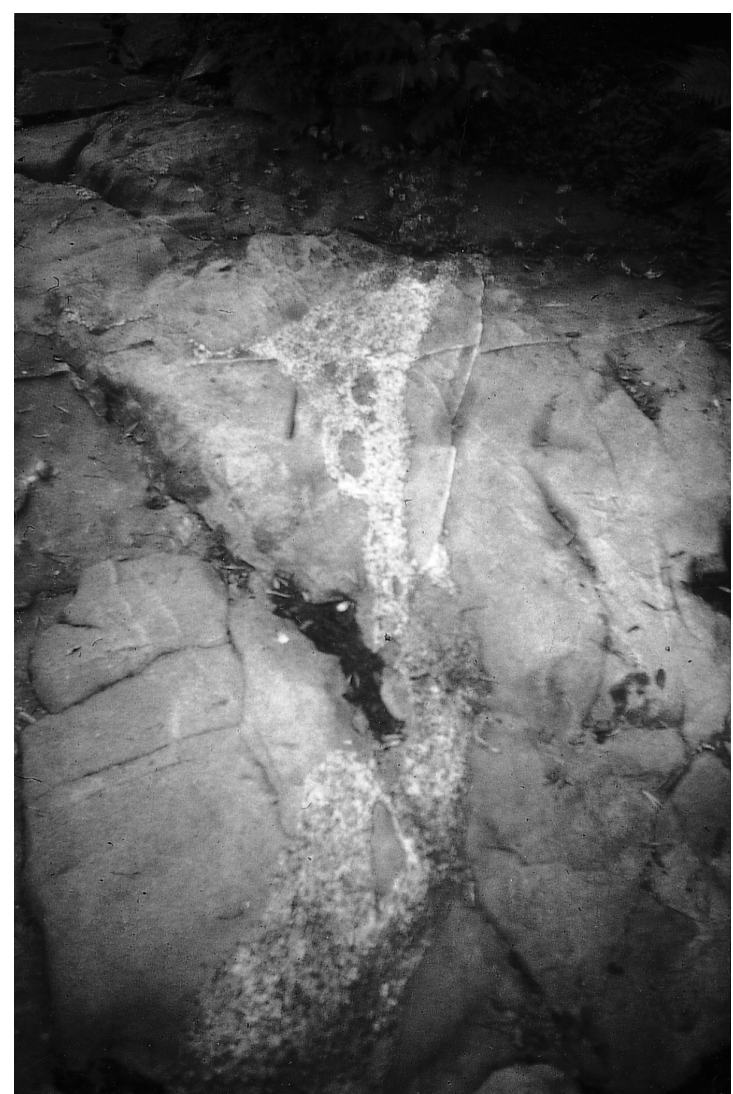

Fig. 4. Felsic amoeboidal or ribbon-like layers within the fine-grained gabbro in the Järvikulma area (Site 2). Photo by the author.

blendite MMEs in the monzonite. The contacts between layers are cuspate. The hornblendite grades gradually to a fine-grained mafic layer, followed by a sharp contact with a monzonitic layer. The overlaying felsic layer is mainly composed by tightly packed rapakivi-textured K-feldspar ovoids, which are also found in the ultramafic layer below. This sequence resembles the macrorhythmic unit of the Pleasant Bay Gabbro-Diorite, described by Wiebe (1993b).

The area shows also medium- to fine-grained gabbroic layers alternating with irregular ribbonlike or amoeboid leucocratic hybrid layers (Fig. 4). The felsic layers carry ellipsoid MMEs with cuspate margins, captured from the mafic layers. The contacts between layers of different compositions are cuspate, and the mafic layers have chilled margins against the felsic layers. The felsic layers show flame and load-cast structures on their top, in contact with the base of the mafic layers. Felsic pipes intrude the mafic layers. Some $\mathrm{K}$-feldspar xenocrysts occur in the mafic layers, and the felsic layers have tightly packed rapakivi-textured K-feldspar ovoids as cumulates.

The structures of the Central-Western Zone are similar to those described by Wiebe (1993a, 1996) and Wiebe and Collins (1998) in the mafic-silicic layered intrusions and stratified composite intrusions. They probably indicate intrusion of mafic magma into a silicic magma chamber (e.g. Wiebe 1993b, 1994). Due to its greater density, the mafic magma flows on the floor and accumulates in layers on the bottom of the felsic magma chamber (Campbell \& Turner 1989). There the felsic magma is trapped between the mafic layers, forming cumulatic felsic layers (Wiebe 1993a, Snyder \& Tait 1995, Wiebe \& Collins 1998, Bergantz 2000).

Because felsic magma is less dense than the mafic one, it attempts to rise through the mafic layers. This process results in crenulated and ribbonlike or amoeboid contacts, flame and load-cast structures between mafic and felsic magmas, felsic pipes, and finally, disruption of mafic magmas and consequent formation of MMEs in the form of pillows (Snyder \& Tait 1995, Wiebe 1996, Wiebe \& Collins 1998). Similar features could also be generated by intrusion of felsic magma into the mafic magma chamber and this is even more efficient in producing magma mingling and mixing, especially when mafic magma is more voluminous than the felsic one (Wiebe 1987a,b, Koyaguchi \& Blake 1991, Weinberg 1997). Alternation of fine-grained mafic and ultramafic layers suggests new magma pulses (Snyder \& Tait 1995, Wiebe \& Collins 1998, Semenov et al. 2000).

\section{The South-Central Zone: MMEs}

In the following, MMEs are described in three areas of the South-Central Zone; at Rajamäki, Kupinmäki, and Haanmäki.

The Rajamäki area is located at the southernmost extremity of Lake Kilpijärvi, west of Site 3 
in Fig. 2. It shows MMEs in the form of tightly packed pillows. They are of different sizes and are surrounded by anastomosing veins of monzonite (Fig. 6 in Eerola \& Törnroos 2000), which contain rapakivi-textured K-feldspar ovoids. The contacts of the mafic pillows and felsic veins are crenulated. Grain-size and amount of K-feldspar xenocrysts in the pillows vary widely. Clots of hornblende and biotite are common in the most coarse-grained varieties of pillows. Surrounding pillows deformed one of the pillows and all the pillows are molded against the K-feldspar ovoids of the felsic veins, showing that the pillows behaved in a plastic manner (e.g. Wiebe 1991, Wiebe $\&$ Collins 1998). This may also be the reason for preferred orientation of its mafic clots and xenocrysts. There are also light brown, rounded or ellipsoid microgranitoid enclaves with few if any K-feldspar xenocrysts and zoned plagioclase crystals, indicating their magmatic origin. This arrangement of mafic pillows hosted by anastomosing felsic veins is also known as net veining (see Lindberg \& Eklund 1988, Wiebe 1991, Pitcher 1993, Hall 1996). The association is also found in cliffs on the SW side of Kilpijärvi (Härme 1978). According to Wiebe (1991), it represents accumulation of sinking mafic pillows on a granitic crystal mush, which penetrates them in the form of veins.

The Kupinmäki area (Site 3 in Fig. 2) shows typical MMEs hosted by porphyritic monzonite (Fig. 5 in Eerola \& Törnroos 2000). The MMEs are fine grained, homogeneous and green-gray, and they have cuspate and chilled margins against the felsic magma. The largest MMEs are up to 2 $\mathrm{m}$ in diameter and are stretched towards north, indicating magma flow (see Vernon et al. 1988). Kfeldspar xenocrysts in the MMEs are ovoids or euhedral grains. Rapakivi texture is rare or absent. Quartz ocelli are not found, as there is practically no quartz in the host rock. Hornblende-biotite patches surrounding partially consumed K-feldspar xenocrysts are common. Blebs of monzonite intruded some of the MMEs in the form of diapirs or pipes. These are also found as "enclaves" within the MMEs. This is related to a tendency of felsic crystal mush to dismember mafic mag- ma, forming smaller MMEs by disruption. Some of the MMEs are intruded by aplitic veins by back veining of the host. This is due to partial melting of the host when the MME starts to become brittle and is fractured despite its higher temperature compared to the host (Barbarin 1988, Pitcher 1993, Neves \& Vauchez 1995, Nardi \& Lima 2000). In addition, a swarm of smaller and tightly packed MMEs in process of disruption is found in the Kupinmäki area.

The Haanmäki area (north of site 3 in Fig. 2) shows alternation of irregular mafic and silicic amoeboid and ribbon-like layers, similar to those found at Järvikulma. There are also mafic pillows surrounded by monzonitic veins, including rapakivi-textured K-feldspar xenocrysts, hornblendebiotite patches, and fine-grained granitic xenoliths, forming double or composite enclaves (Fig. 5). This indicates that MMEs captured already crystallized granitic enclaves; this is one of the strongest evidence for magmatic behavior of MMEs (Vernon 1986, Barbarin 1988). The most classic and smaller MMEs are found in this area (Fig. 6). The MMEs are stretched towards north, evidencing direction of magma flow.

The South-Central Zone probably represent an area where the mafic magma, injected into the silicic magma chamber, was disrupted by felsic magma, forming MMEs as a result of flow-front instability (see Snyder \& Tait 1995, Wiebe \& Collins 1998). This pillow zone forms a layered concentric structure, surrounding the S-SE part of Lake Kilpijärvi. This kind of layering is common in the stratified composite intrusions described by Wiebe (1994) and Wiebe and Collins (1998).

\section{Eastern zone - layering of hornblendite and syenite and disrupted mafic dykes or sheets in granite}

\section{Peltolanmäki}

The hornblendite-gabbroic body with felsic parts in the Peltolanmäki area, NW of Site 4 (Fig. 2), was mapped as an intrusive syenite by Kaitaro (1956). It was considered by Härme (1978) to represent granitization of a gabbro by potassium 


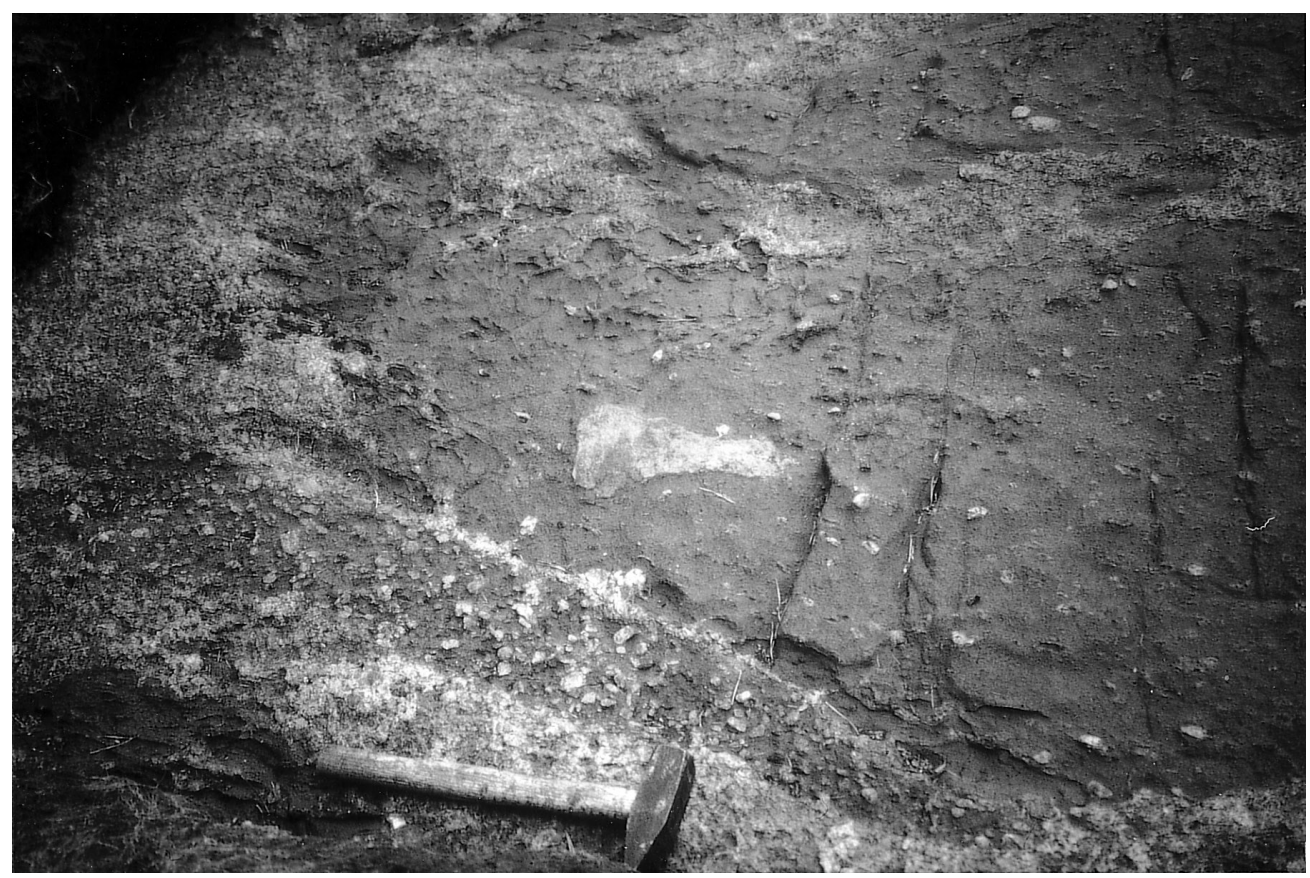

Fig. 5. Mafic pillow with K-feldspar xenocrysts and granitic double-enclave, surrounded by monzonitic veins. Haanmäki, south-central Soukkio Complex. Photo by the author.

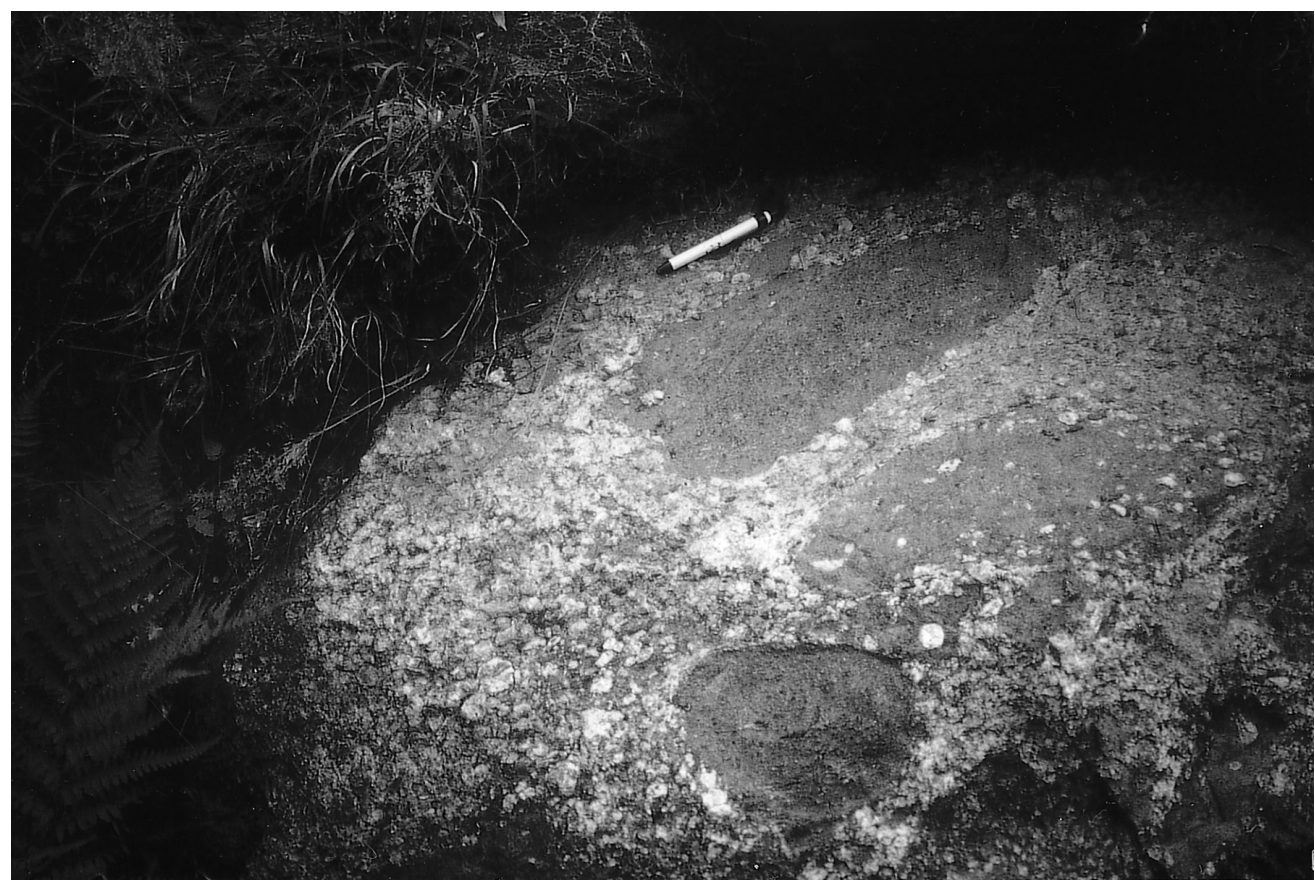

Fig. 6. Typical MMEs in the Haanmäki area. Photo by the author. 


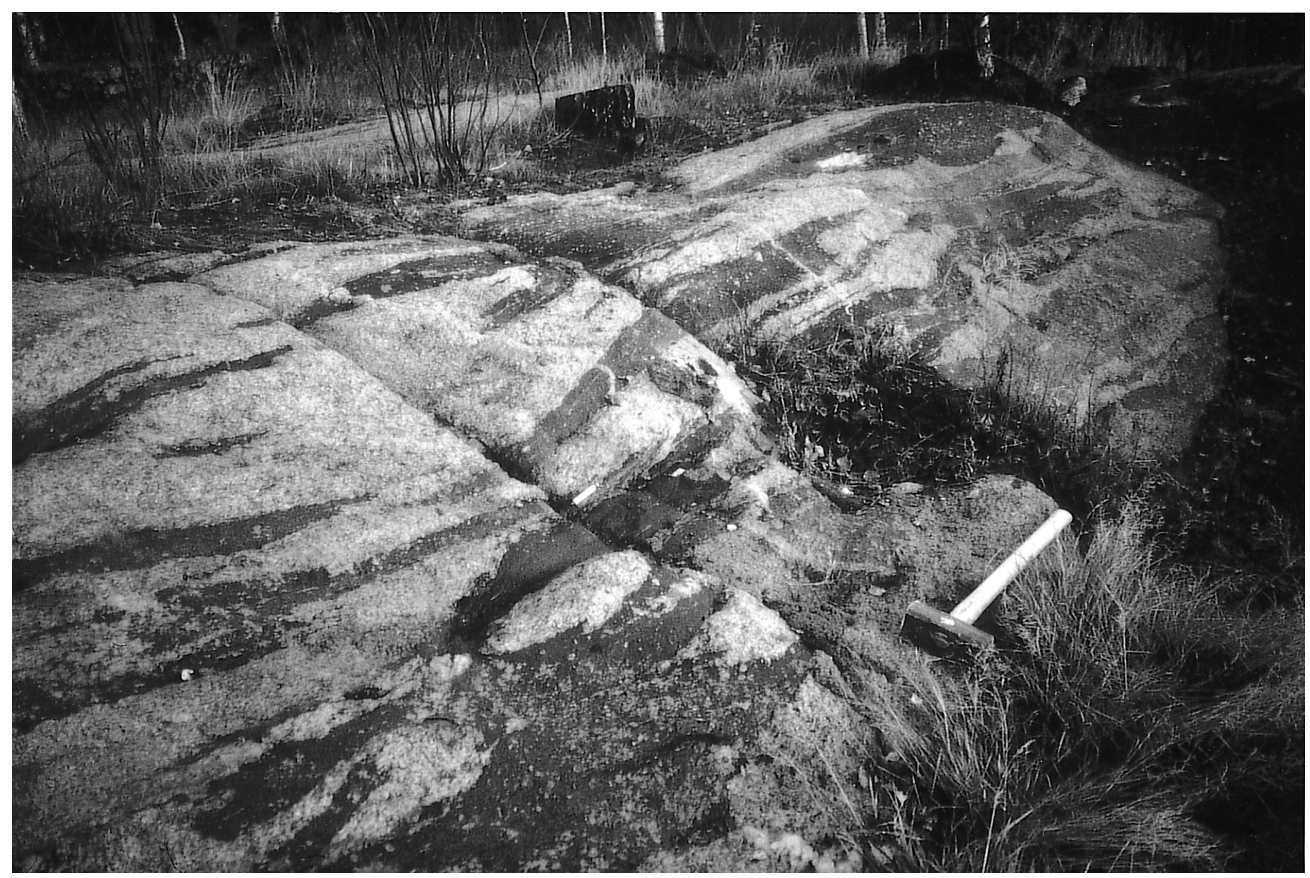

Fig. 7. Mafic synplutonic dykes or sheets in granite at Soukkio. The outcrop shows enclave types 1-4 as well as intermediate types. The enclave type 4 underlays the white pen (the darkest enclave at the center). Eastern margin of the Soukkio Complex (Site 4). Photo by the author.

metasomatism. The mafic enclaves included in the felsic part were interpreted as xenoliths by Härme (1978). In fact, felsic layers with composition close to syenite with abundant rapakivi-textured K-feldspar augens and MMEs alternate with cumulatic mafic-ultramafic layers. This body is an intensively sheared cumulatic unit with trapped felsic layers. It dips gently to the west, as do other units in the Eastern Zone. The hornblenditegabbroic part of the body has pockets with appinitic texture, i.e. $2-5 \mathrm{~cm}$ long acicular hornblende phenocrysts. This layered zone is surrounded by leucotonalites and leucogabbros with some MMEs (e.g. Site II in Fig. 2).

The Peltolanmäki area represents probably a lower zone of the Soukkio Gabbro, corresponding with the Sarkasuo cumulates on the western side. A monzosyenitic composition could have been achieved by interaction of two contrasting magmas (e.g. Dobnikar et al. 2000) and accumulation of K-feldspar in trapped felsic layers (e.g. Wiebe 1993a). Interaction between the contrasting compositions is suggested by the mafic-felsic layering of the body and widespread occurrence of MMEs with K-feldspar xenocrysts. The appinitic texture is generally associated with lamprophyres and magma mingling and mixing (Ayrton 1991). The spectacular growth of hornblende phenocrysts in the mafic body was probably caused by water derived from the interacting felsic magma (ibid.).

The leucotonalites and leucogabbros with some MMEs (Site II in Fig. 2) suggest magma mixing, probably corresponding with the Punahiedanmäki zone on the western side of the intrusion.

\section{Soukkio}

The eastern border of the Soukkio Complex is porphyritic quartz monzonite to granite in composition. There are disrupted mafic and felsic synplutonic dykes or sheets which occur as elongated and comformable MMEs in the host (Fig. 7), forming schlieren, a typical feature of this kind of association (Barbarin 1991, Bussel 1991, Didier \& Barbarin 1991b, Pitcher 1991, Neves \& Vauchez 
Table 2. Summary of characteristics of the synplutonic dykes or sheets and enclaves in granite in the Eastern Zone of the Soukkio Complex (Site 4).

\begin{tabular}{cl}
\hline Type of enclaves & Characteristics \\
\hline Type 1 & $\begin{array}{l}\text { Common, mafic, dark-gray, fine- to medium-grained, crenulated contacts, K-feldspar } \\
\text { xenocrysts, rapakivi texture, quartz ocelli, double enclaves, hornblende-biotite patches }\end{array}$ \\
Type 2 & $\begin{array}{l}\text { Rare, mafic, light-gray, coarse-grained, crenulated contacts, K-feldspar xenocrysts }(\varnothing=10 \mathrm{~cm}), \\
\text { rapakivi texture }\end{array}$ \\
Type 3 & $\begin{array}{l}\text { Common, felsic, pink-light gray, diffuse contacts, abundant K-feldspar xenocrysts, rapakivi } \\
\text { texture, quartz ocelli }\end{array}$ \\
Type 4 & Rare, mafic, gray, foliated, K-feldspar rare or absent, probable xenolith \\
\hline
\end{tabular}

1995). Their orientation is N-S and the association is deformed. This association can be seen best at Site 4 of Fig. 2. There is also a small educational geosite (108 in Fig. 2) with provincial importance, representing the same association, but proposed to be conserved as an example on granitization of gabbro by Kananoja and Grönholm (1993). Four main types of MMEs can be observed and are described below; see Table 2 for summary.

Type 1 is the most common type and is medium-grained, elongated, sheet-like MME with dimensions varying from 0.3 to $5 \mathrm{~m}$ in length and up to $0.5 \mathrm{~m}$ in width. Hornblende-biotite patches are common. The contact with the surrounding granite is cuspate, and the sheets host several Kfeldspar xenocrysts, which vary from euhedral to ovoid and have rapakivi texture (Fig. 3b in Eerola et al. 2000 and Fig. 8). Quartz ocelli, with similar size and shape as quartz grains in the granite, also occur in the MMEs. Acicular apatite grains can be seen under the microscope. There are also few double or composite enclaves, i.e., the MMEs host pieces of disrupted coarse-grained cumulatic ultramafic rocks, which were captured by them.

Type 2 consists of coarse-grained, several meters long and ca. 1 meter wide sheet-like MMEs, composed mainly of hornblende and plagioclase, with cumulate texture. They resemble the leucogabbro occurring at Site II in Fig. 2, but are relatively rare. They host numerous K-feldspar xenocrysts with varying diameters and rapakivi texture. The largest K-feldspar megacryst ovoid has a diameter of $10 \mathrm{~cm}$, which is much greater than in the granite host, in which the K-feldspar grains have a maximum diameter of 2-3 cm (Fig. 7).
Type 3 is represented by felsic, pink to light grey, fine-grained, elongated intermediate and some tens of centimeters to several meters long and $5 \mathrm{~cm}$ to $0.5 \mathrm{~m}$ wide sheets (Fig. 7). Some of the sheets have diffuse contacts with the host and are rich in K-feldspar xenocrysts and quartz ocelli. Quartz ocelli are of the same size as the quartz phenocrysts in the host. The sheets probably represent readily hybridized MMEs.

Type 4 is very fine-grained, strongly to weakly foliated, elongated, grey enclave (Fig. 7). There are some mafic clots similar to those in Type 1, but only few K-feldspar phenocrysts are found. Enclaves of this type are extremely rare. Due to their strong foliation and fine grain size, they could be supracrustal xenoliths (schists) or strongly sheared MMEs.

Both the host and the enclave types are cut by aplitic dykes originated from the granite and oriented parallel to the mafic sheets (Fig. 3a in Eerola et al. 2000). This is typical for deformed dykes where silicic vein material is commonly transposed parallel to the main planar fabric (Bussell 1991). These silicic dykes may represent back veining by the granite, which was partially melted due to the still high-temperature mafic magmas (ibid.).

The presence of rapakivi textured K-feldspar ovoids and euhedral crystals, both in the host quartz monzonite and granite and in the MMEs, is essentially a magmatic feature (Vernon 1986, Bussy 1990, Eklund \& Shebanov 1999). Ovoids with mantled plagioclase rims suggest thermal disequilibrium between the host and the mafic rock, and this texture is common in magma mingling 


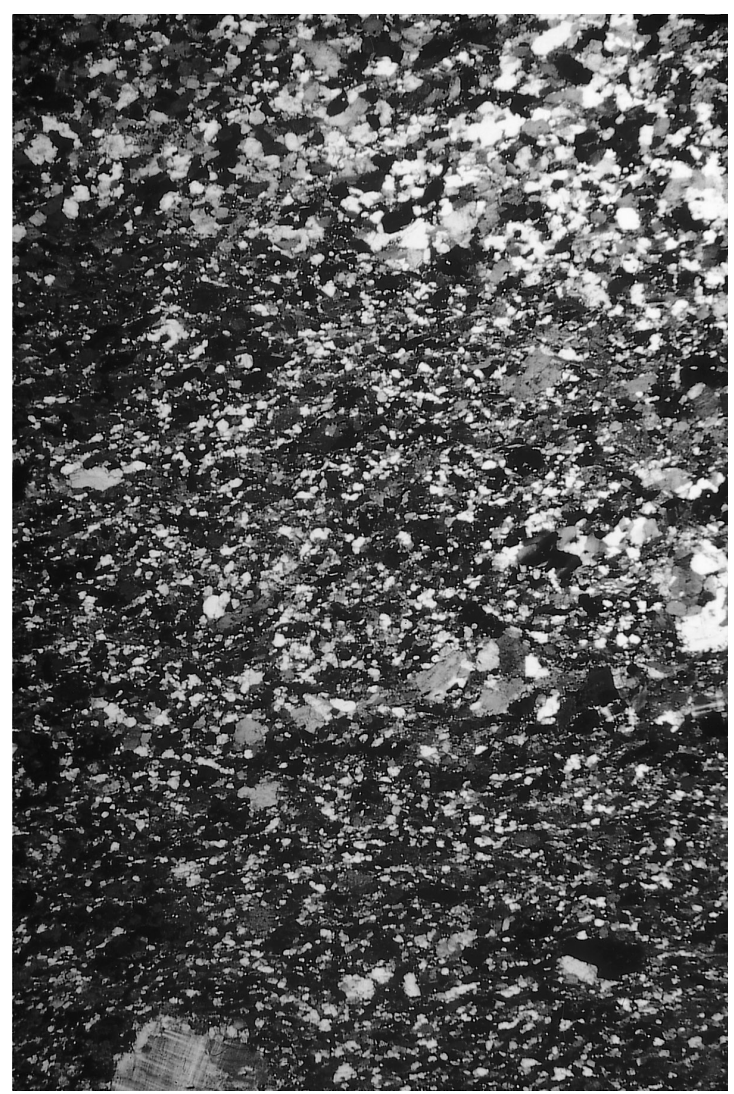

Fig. 8. A photomicrograph showing the contact between granite (coarse-grained, upper side) and MME (finegrained, lower side) and part of K-feldspar ovoidal xenocryst surrounded by plagioclase rim (lower left). Length of the thin section is $5 \mathrm{~cm}$. Soukkio, Site 4. Photo by the author.

and mixing (Hibbard 1981, Vernon 1983, 1984, Bussy 1990, Sylvester 1998, Lowell \& Young 1999). K-feldspar megacrysts occur more commonly only in enclaves of probable igneous origin, even where there is a mixed population of xenoliths and MMEs (Pitcher 1993). A magmatic origin of the MMEs is also suggested by the presence of double or composite enclaves in them (cf. Vernon 1986, Barbarin 1988, 1991, Bussel 1991).

According to Eklund and Shebanov (1999), the megacrystic K-feldspar xenocrysts $(\varnothing=10 \mathrm{~cm})$ suggest a frozen situation where xenocryst was captured by the MME at a greater depth than that represented by smaller K-feldspars in the host. When the granite was ascending in the crust, the grain size of K-feldspars in the host was reduced by resorption due to decreasing lithostatic pressure. However, the original grain size was preserved in some MMEs because of their higher temperature, which protected them from resorption (Eklund \& Shebanov 1999). In fact, the coarse grain size and cumulate texture of Type 2 MME could indicate that it intruded at an early stage as synplutonic dyke in a deep part of the magma chamber (e.g. Barbarin 1991). However, for R. Wiebe (pers. comm. 2001) it may be a cumulate sheet that forms a layer, which is a common feature in the stratified composite intrusions that show interaction of contrasting magmas (Wiebe \& Collins 1998).

The presented observations suggest magma mingling and mixing that is typical on the margins of granitic magma chambers with early fractures into which mafic magma intruded as synplutonic dykes (e.g. Barbarin 1988, Bussel 1991, Pitcher 1991, Neves \& Vauchez 1995, Salonsaari 1995, Sylvester 1998, Mellqvist 1999, Xu et al. 1999), sills (Michael 1991) or as disrupting sheets flowing on a sloping floor of a magma chamber (Wiebe \& Collins 1998). When a dyke or a sheet is emplaced into a visco-plastic felsic host, it is disrupted due to flow of the host magma, generating MMEs (Barbarin 1991, Bussel 1991, Pitcher 1991, Neves \& Vauchez 1995, Salonsaari 1995, Wiebe \& Collins 1998, Mellqvist 1999). However, as observed by Pitcher (1991), deformation makes it difficult to determine the correct origin of the elongated MMEs.

\section{GEOCHEMISTRY OF THE SOUKKIO COMPLEX}

The geochemical evidence for magma mixing can be ambiguous (Michael 1991, Hall 1996, Nardi \& Lima 2000) but it has still been widely used to study the phenomena (e.g. Barbarin 1988, Lindberg \& Eklund 1992, Salonsaari 1995, Lowell \& Young 1999, Xu et al. 1999).

Geochemical data of 25 samples selected from the 59 samples analyzed by Eerola (2000) of the Soukkio Complex and its enclaves is presented in Table 3. The samples were collected from Sites 


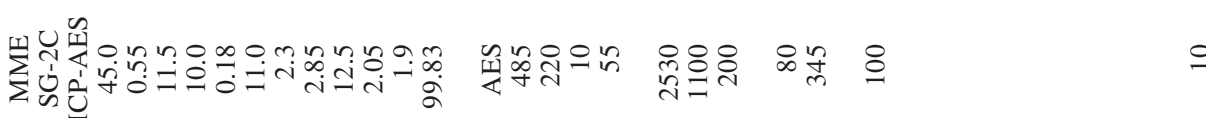

$\frac{\sqrt{2}}{\sqrt[2]{2}}$

音望

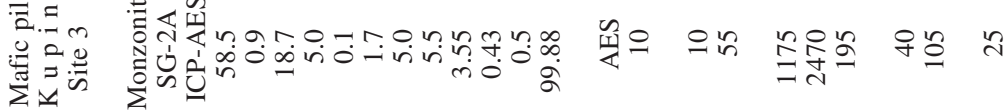

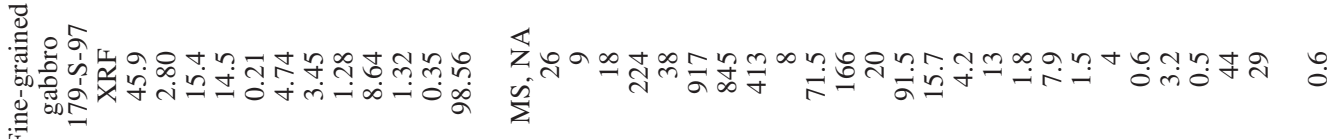

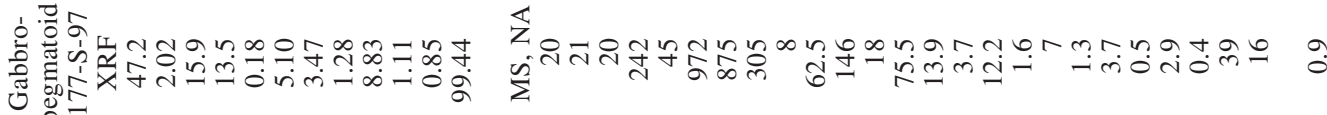

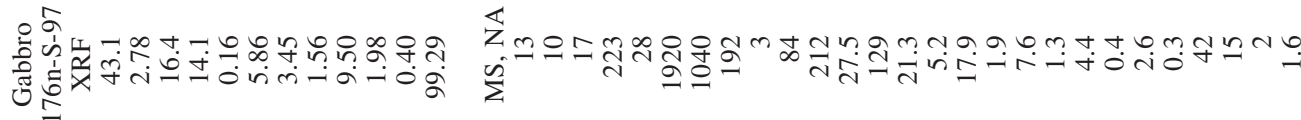

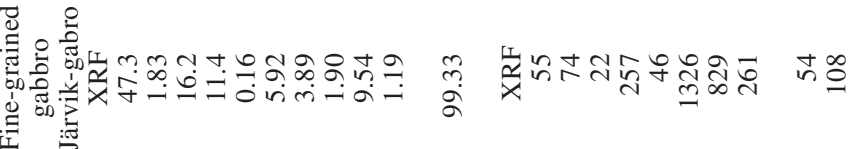
पृत्रा

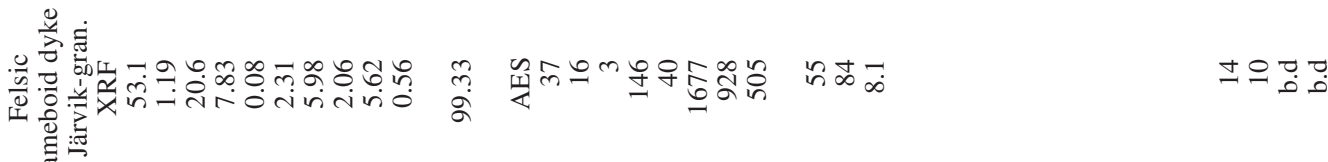

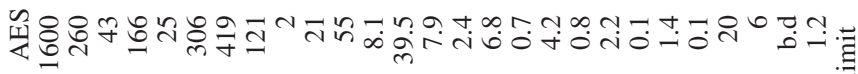

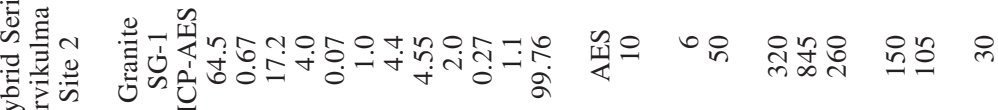

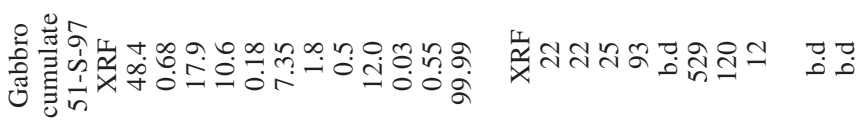
$\rightarrow \quad \frac{0}{0}$

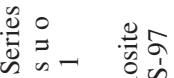

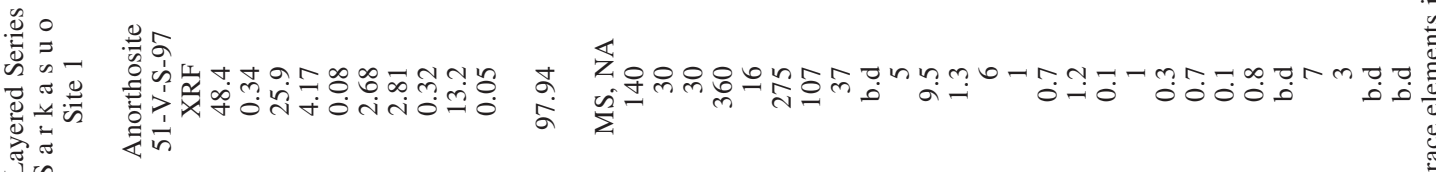




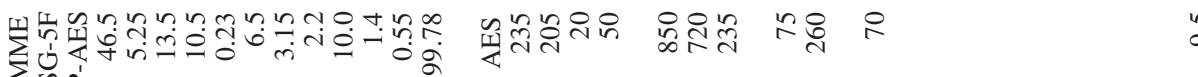

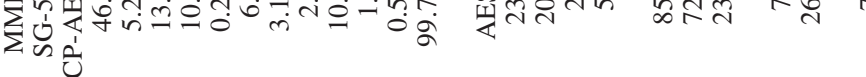

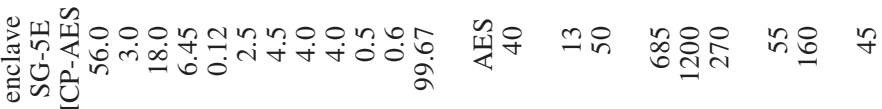

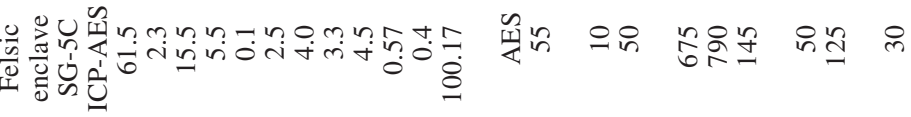

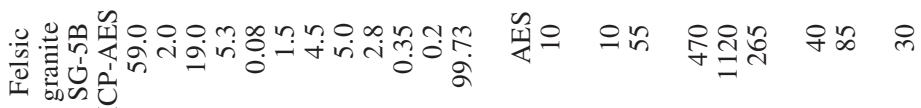

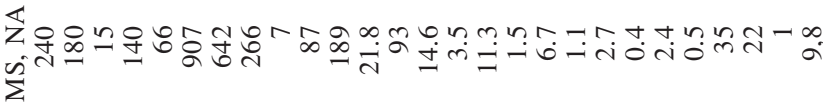

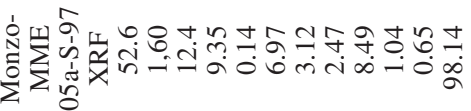

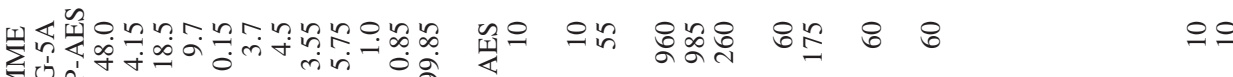

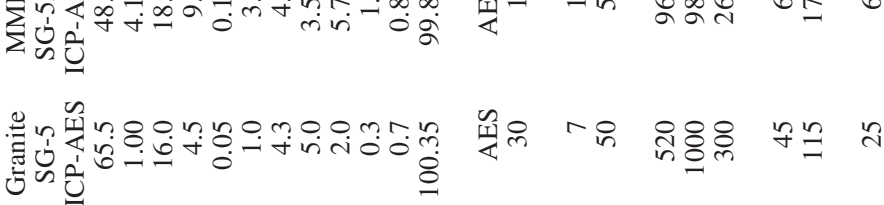

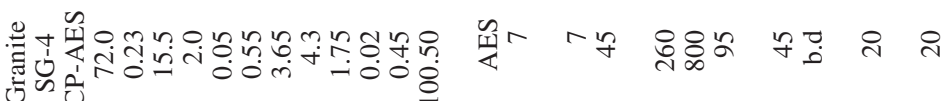

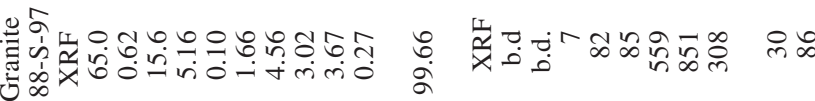

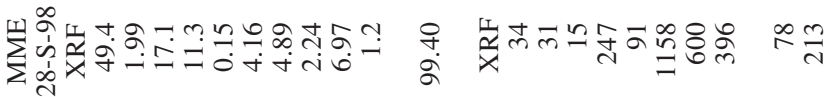

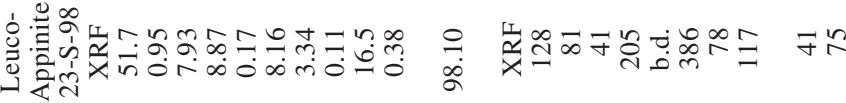

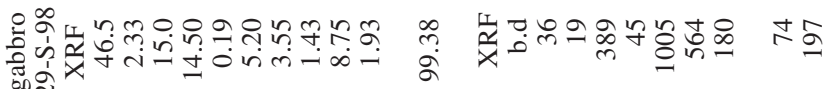


1-4 along a NW-SE profile through the main units of the complex (Fig. 2, Table 3). They were taken with hammer, avoiding weathered surfaces, veins and fractures.

\section{Analytical methods}

The whole-rock samples were analyzed at X-Ral in Canada, Geochemical Laboratory of the Geological Survey of Finland (GTK) and Geochemical Laboratory of the Department of Geology, University of Helsinki (UH). The analyses at X-Ral were made using X-ray fluorescence (XRF), inductively coupled plasma mass spectrometry (ICP-MS) and neutron activation (NA). The analyses performed at GTK and the University of Helsinki were made using XRF and inductively coupled plasma atomic emission spectrometry (ICP-AES), respectively. The samples were jaw crushed, and the splits were pulverized in a tungsten-carbide bowl for XRF analyses and in a carbon steel bowl for ICP-MS analyses. Major elements and $\mathrm{Rb}, \mathrm{Sr}, \mathrm{Y}, \mathrm{Zr}, \mathrm{Nb}$ and $\mathrm{Ba}$ were determined by XRF. The rare earth element (REE) determinations were made at X-Ral using NA and ICP-MS. Detection limits of the GTK and UH analyses for the minor and trace elements are 20 ppm for $\mathrm{Ba}, 10 \mathrm{ppm}$ for $\mathrm{Zr}$ and $\mathrm{Nb}, 5 \mathrm{ppm}$ for $\mathrm{Rb}$, $\mathrm{Sr}$ and $\mathrm{Y}, 0.25 \mathrm{ppm}$ for $\mathrm{Nd}, 0.2 \mathrm{ppm}$ for $\mathrm{Sm}$ and Ta, 0.15 ppm for Ce, Gd, Dy, Er and Yb, 0.1 ppm for $\mathrm{La}, \mathrm{Pr}$ and $\mathrm{Lu}$, and 0.05 ppm for $\mathrm{Eu}, \mathrm{Tb}, \mathrm{Ho}$ and $\mathrm{Tm}$. Detection limits of the X-Ral analyses for major elements are $0.01 \%$, except $0.001 \%$ for $\mathrm{TiO}_{2}, 0.5$ ppm for Th, 20 ppm for $\mathrm{Ba}, 2 \mathrm{ppm}$ for $\mathrm{Zr}, \mathrm{Nb}, \mathrm{Cr}$, $\mathrm{V}$ and $\mathrm{Rb}, 1 \mathrm{ppm}$ for $\mathrm{Ni}, \mathrm{Y}$, Ta and $\mathrm{Hf}, 0.05 \mathrm{ppm}$ for Sr, Th, Lu, Eu and Sc, 0.02 ppm for Pr, and 0.01 ppm for Yb, La, Ce, Nd, Sm, Gd, Tb, Dy, Er and $\mathrm{Tm}$. The estimated uncertainty is $1-5 \%$ for major elements and $3-10 \%$ for trace elements.

\section{Major elements}

In the classification diagram (Fig. 9a), the gabbro samples of the Soukkio Complex plot in the gabbro and monzogabbro fields whereas the granitoid samples are dispersed in the monzodiorite, monzonite, quartz monzonite and granite fields. Most of the MMEs fall in or close to the monzogabbro
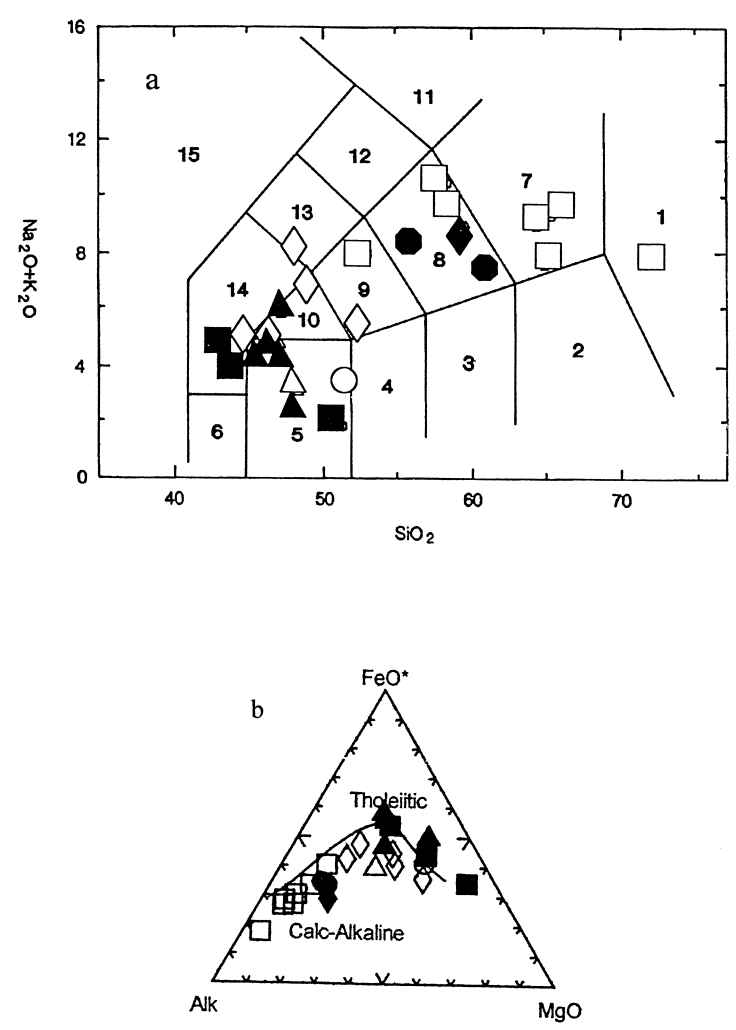

Fig. 9. a) Rock classification diagram (Middlemost 1994) with analyses of the Soukkio Complex. Data from Table 3. Fields: 1 = granite; $2=$ granodiorite; $3=$ diorite; 4 = gabbroic diorite; 5 = gabbro; $6=$ peridot ite-gabbro; 7 = quartz monzonite (lower zone) and syenite (upper zone); 8 = monzonite; 9 = monzodiorite; 10 = monzogabbro $; 11=$ foid syenite $; 12$ = foid monzosyenite; 13 = foid monzodiorite; 14 = foid gabbro . Symbols: Open triangle = anorthosite; filled triangle = gabbro; open square = granitoid; filled square $=u l$ tramafic rock; open diamond = MME, filled diamond = syenite ; open circle = appinite filled circle $=$ felsic enclave. b) AFM-diagram (Irvine \& Baragar 1971), with data from Table 3 and symbols as in Fig. 9a.

field, one sample in the foid monzodiorite field, and the felsic enclaves are monzonitic. In general, the enclaves tend to be intermediate between the gabbro and granitoid samples. The hybrid "syenite" has also a monzonitic composition. The granitoids are peraluminous with $\mathrm{Al}_{2} \mathrm{O}_{3} /$ $\left(\mathrm{CaO}+\mathrm{Na}_{2} \mathrm{O}+\mathrm{K}_{2} \mathrm{O}\right)$ values ranging from 1.33 to1.69 (figure not shown, calculated from Table 3).

On the AFM diagram (Fig. 9b), the gabbro sam- 


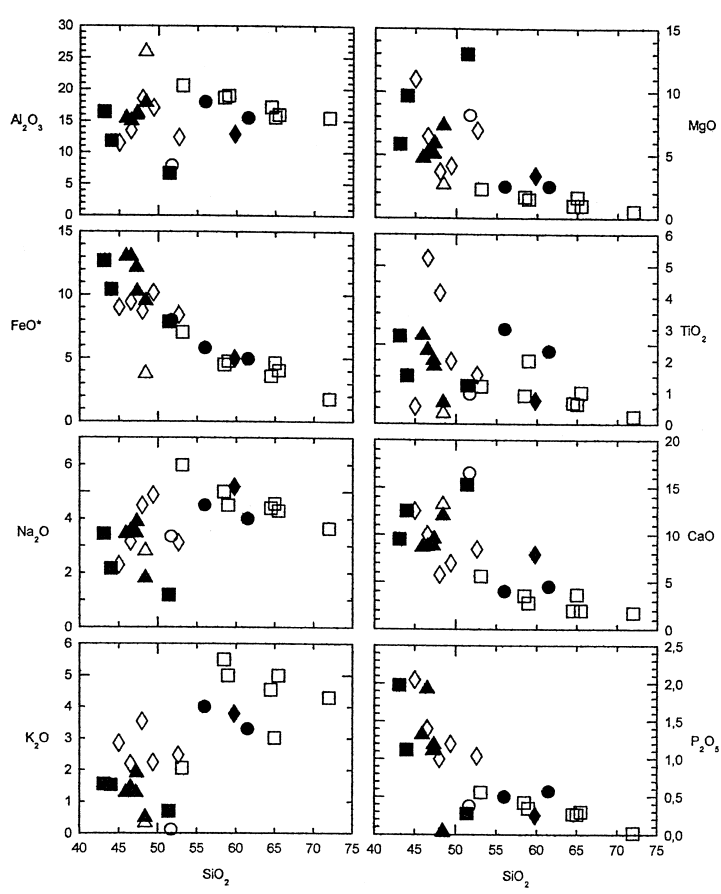

Fig. 10. a) Harker diagram with major-element data from Table 3 and symbols as in Fig. 9a.

ples largely follow the tholeiitic trend while the granitoids and enclaves plot in the calc-alkaline field. The enclaves are again intermediate between the gabbro and granitoid samples.

In the Harker diagrams (Fig. 10a), most of the granitoid samples define decreasing trends with increasing $\mathrm{SiO}_{2}$ for all major elements, possibly indicating fractionation. The relatively low $\mathrm{K}_{2} \mathrm{O}$ (together with the low $\mathrm{SiO}_{2}$, for a granitoid) in the amoeboid leucocratic layer at Järvikulma emphasizes its hybrid character. The rather high $\mathrm{K}_{2} \mathrm{O}$ (3.0-5.5 wt\%) in the typical granitoids might be a sign of crustal contamination by pelites, supported by the presence of abundant large pink K-feldspar phenocrysts (cf. Hall 1996). However, the $\mathrm{K}_{2} \mathrm{O}$ content in the Soukkio granitoids is considerably lower than in the late-orogenic $1.83 \mathrm{Ga}$ potassium granites ( 9 wt\%, Härme 1978). The felsic enclaves in general fall on the trends of the granitoids but tend to be lower in $\mathrm{K}_{2} \mathrm{O}$ and slightly higher in $\mathrm{TiO}_{2}$ than the latter typically.

The MMEs are concentrated near or together

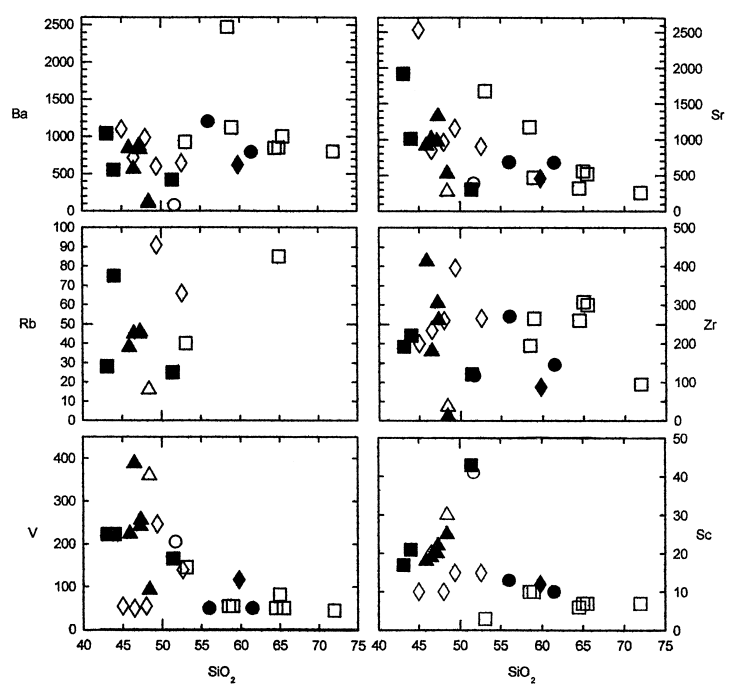

b) Harker diagram with trace-element data from Table 3 and symbols as in Fig. 9a. For Zr, Järvikylä granitoid sample with $505 \mathrm{ppm} \mathrm{Zr}$ and ca. 53 wt\% $\mathrm{SiO}_{2}$ is not shown.

with the gabbroic samples in the Harker diagrams but both groups show considerable dispersion for most major elements. The scattering among the gabbros is in part due to more or less cumulative character of the samples; e.g. the gabbro highest in $\mathrm{SiO}_{2}$ is cumulate sample 51-S-97 (Table 3) and it has distinctly lower contents of $\mathrm{P}_{2} \mathrm{O}_{5}, \mathrm{~K}_{2} \mathrm{O}, \mathrm{Na}_{2} \mathrm{O}$ and $\mathrm{TiO}_{2}$ than the other gabbros. A part of the dispersion might be caused by fractionation of olivine and pyroxenes.

The MMEs have, in general, higher $\mathrm{K}_{2} \mathrm{O}$ than the gabbros while the latter tend to be higher in $\mathrm{FeO}^{*}$. The relatively high $\mathrm{K}_{2} \mathrm{O}$ contents could be explained by interaction of the MMEs with the granitoid magmas (change of K-feldspar xenocrysts), which are even higher in $\mathrm{K}_{2} \mathrm{O}$. With increasing $\mathrm{SiO}_{2}$, both groups show steep decreases in $\mathrm{TiO}_{2}$. A similar decrease in $\mathrm{FeO} *$ is found for the gabbros and in $\mathrm{MgO}$ for most of the MMEs. A possible reason for the scattering among the MMEs may be fractionation (e.g. Andersson 1991, Michael 1991). 


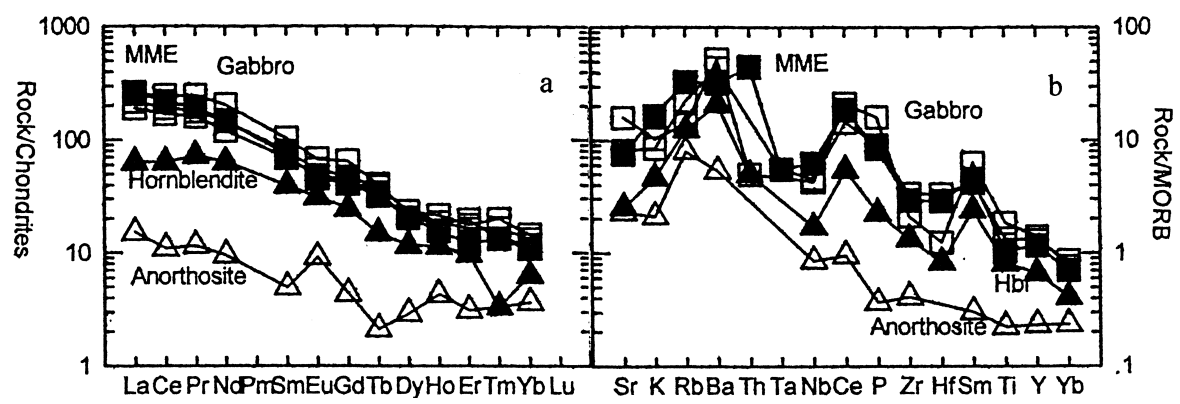

Fig. 11. a) Chondrite-normalized REE patterns (Nakamura 1974) with data from Table 3. Symbols: Open triangle $=$ anorthosite; filled triangle $=$ hornblendite; open square $=$ gabbro; filled square $=$ MME. $b)$ MORB-normalized incompatible element diagram (Pearce 1983) with data from Table 3 and symbols as in Fig. 11a.

The gabbros, MMEs, felsic enclaves and granitoids together define largely linear, negative slopes for $\mathrm{CaO}, \mathrm{MgO}, \mathrm{FeO}^{*}$ and $\mathrm{P}_{2} \mathrm{O}_{3}$, but among the mafic rocks the trends tend rather be curvilinear due to the wide dispersion there. The generalized trend for $\mathrm{Al}_{2} \mathrm{O}_{3}$ is practically horizontal, and $\mathrm{K}_{2} \mathrm{O}$ shows a positive trend, with a wide scatter, however. The partly linear trends might indicate a magma mixing system (cf. Salonsaari 1995, Lowell \& Young 1999).

Some elements $\left(\mathrm{MgO}\right.$ and $\left.\mathrm{TiO}_{2}\right)$ show two possible mixing lines involving gabbros, MMEs, felsic enclaves and granitoids, but with a similar granitic end member at $72 \mathrm{wt} \% \mathrm{SiO}_{2}$. This might result from fractionation among the enclaves (cf. Andersson 1991).

Two MMEs have relatively high contents of $\mathrm{TiO}_{2}$. In particular, the sample from the mafic dyke/sheet (SG-5F) has ca. $5 \mathrm{wt} \%$ of $\mathrm{TiO}_{2}$, which is much higher than in the Soukkio gabbroic rocks typically (ca. 0.3-2.8 wt\%, Table 3). Based on Michael (1991), Wiebe and Snyder (1993), Xu et al. (1999) and Nardi and Lima (2000), this could represent the original $\mathrm{TiO}_{2}$ content of the mafic magma or its enrichment in mafic enclaves.

The combination of linear, curvilinear and scattered trends on the variation diagrams indicates that several processes influenced the compositions of the rocks. It should be also emphasized that many of the gabbro samples are cumulative and do not represent proper compositions of melts. These points might suggest that crystal fractionation was more important than magma mixing. This would be in agreement with the field observations that magma mingling is more common than mixing. In addition, typical mixing lines may not be observed if there were several mixing episodes (Nardi \& Lima 2000) and/or if the initial end member compositions were not exactly identical for all hybrids and if they changed with time (cf. Andersson 1991).

\section{Trace elements}

Trace elements show similar behavior as the major elements in Harker diagrams (Fig. 10b). MMEs are concentrated near or together with gabbroic samples. Slightly curvilinear, though in part dispersed, trends are observed for $\mathrm{Sr}, \mathrm{V}$ and $\mathrm{Sc}$ involving granitoids, enclaves and gabbroic rocks. The contents of $\mathrm{Sr}, \mathrm{V}, \mathrm{Cr}, \mathrm{Ni}$, and $\mathrm{Sc}$ have negative correlations with the $\mathrm{SiO}_{2}$ content, indicating fractionation of gabbroic rocks. The low concentrations of $\mathrm{Ni}(<250 \mathrm{ppm})$ and $\mathrm{Cr}(<500 \mathrm{ppm}$; Table 3 and Fig. 10b), also suggest that the gabbro does not represent primary magma but evolved through crystal fractionation. High contents of $\mathrm{Ni}$ and $\mathrm{Cr}$ in the cumulatic hornblendite sample at Site 2 (Järvikulma) may indicate its direct mantle provenance and it might represent a new, relatively primitive magma pulse, as suggested above. Transgressive influxes of more primitive magma are common in replenished magma chambers (e.g., in the Newark Island layered intrusion, Wiebe \& Snyder 1993). 

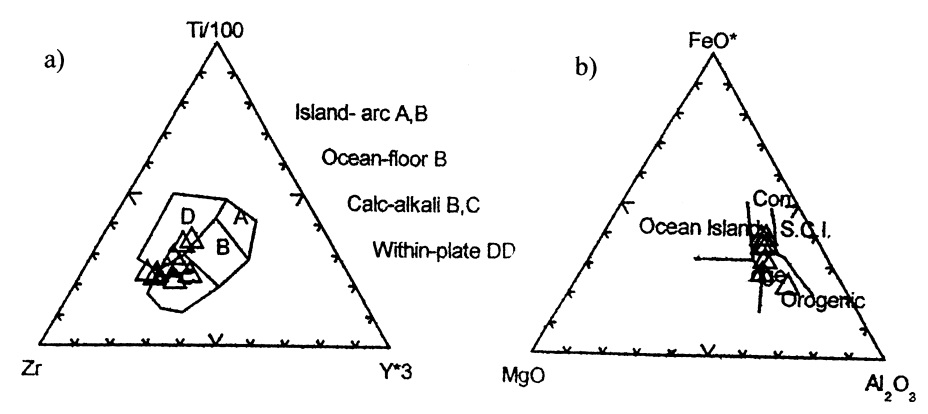

c)

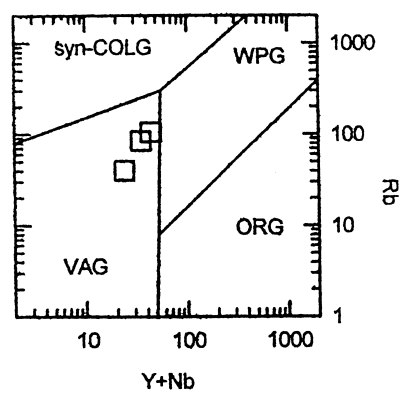

As for some of the major elements, the $\mathrm{V}$ and Sr Harker diagrams show two mixing lines for gabbros, MMEs, felsic enclaves and granitoids, but with a similar granitic end member. This supports the idea, which is based on major elements, that the enclaves were affected by fractionation (cf. Andersson 1991).

Some enclaves are relatively high in $\mathrm{Zr}$. This is, according to Michael (1991), Wiebe and Snyder (1993), Xu et al. (1999) and Nardi and Lima (2000), common in granite-hosted MMEs and could represent original contents of $\mathrm{Zr}$ in mafic magma or its enrichment in MMEs.

The $\mathrm{Ba}$ and $\mathrm{Sr}$ contents of the monzogranites are ca. 60-2500 ppm and 450-1700 ppm, respectively (Table 3, Fig. 10b), and resemble those of the coeval post-kinematic granitoids of the Central Finland Granitoid Complex (see Nironen et al. 2000).

Figure 11a shows that the gabbro samples have REE composition similar to those in the MMEs. This is in accordance with the observations of Salonsaari (1995) and Lowell and Young (1999) that granite-hosted enclaves and coexisting mafic
Fig. 12. a) Tectonic discrimination diagram for mafic rocks (Pearce \& Cann 1973) with data from Table 3. Symbol: Open triangle $=$ gabbro. b) Tectonic discrimination diagram for mafic and intermediate rocks (Pearce et al. 1977) with data from Table 3 and symbols as in 12a. c) Tectonic discrimination diagram for granites (Pearce et al. 1984) with data from Table 3. Open square $=$ granitoid. $V A G=$ volcanic-arc granites, $O R G=$ ocean-ridge granites, $W P G=$ within-plate granites, syn$C O L G=$ syn-collisional granites. magma have similar REE compositions. The hornblendite of the western side is distinguished by its deviating pattern, which could mean a different magma pulse, as suggested above.

\section{Tectonomagmatic discrimination diagrams}

The chemical characteristics of the Soukkio Gabbro, together with the light REE-enriched chondrite-normalized patterns (Fig. 11a) and the $\mathrm{Nb}$ $\mathrm{Ta}$ and $\mathrm{Zr}$-Hf troughs on the MORB-normalized spider diagram (Fig. 11b) are similar to those of island-arc calc-alkaline basalts (cf. Xu et al. 1999). However, they could also indicate the incompatibility of $\mathrm{Nb}, \mathrm{Ta}, \mathrm{Zr}$, and $\mathrm{Hf}$ in the cumulus mineral assemblages and/or contamination by continental crust. It is also noteworthy that Th in part forms a through and that Th content is below the detection limit in most of the samples.

The Soukkio Gabbro samples plot on the boundary between calc-alkali and within-plate fields in Fig. 12a. The samples from the Soukkio Gabbro form a trend from the limit between oce- 
anic ridge and orogenic fields towards the continental field in Fig. 12b. Anorthosite plot on the orogenic field and a cumulate on the limit between the ocean ridge and ocean island fields on the same diagram.

In Fig. 12c, samples from the Soukkio Granitoid fall in the field of volcanic arc granites. They coincide with the field of post-collisional granites (of Pearce 1996, figure nor shown), which straddles the boundary of the fields of volcanic-arc and within-plate granites. In this respect they resemble the coeval post-kinematic granites of the Central Finland Granitoid Complex (Nironen et al. 2000).

\section{DISCUSSION}

The geochemical data show that the gabbros and granitoids of the Soukkio Complex do not belong to the same differentiation trend. It also indicates that the MMEs have compositions similar to the gabbroic samples although, together with the felsic enclaves, they are intermediate between the granitoids and gabbros. The MMEs form slightly curvilinear trends, which may suggest magma mixing. The REE composition of the MMEs is similar to that of the gabbros indicating that they are related to the gabbro. The presence of such MMEs and felsic enclaves in the Soukkio Granitoid supports field observations on interaction of contrasting magmas in the Soukkio Complex. Although magma mixing is suggested by the data, it also evident that magma mingling and crystal fractionation predominated over mixing. Michael (1991) reports a similar case from the Cordillera del Paine Complex in Southern Chile.

The tectonic discrimination diagrams do not give a clear idea on the tectonic setting of the Soukkio Complex. However, its evolution possibly took place during a syn- to late-collisional transition from volcanic arc to continental within-plate setting.

\section{Evolution of the Soukkio Complex: a model}

In complexes with magma mingling and mixing, it is in many cases difficult to determine the or- der of intrusion (Wiebe 1987b, Vernon et al. 1988, Weinberg 1997) and this concerns the Soukkio Complex as well. In general, however, a granitic magma formed by anatexis is underlain by the mafic magma responsible for the melting event (Hall 1996). Various field relationships between felsic and mafic rocks have been interpreted as a result of juxtaposition of magmas and they are useful in deducing intrusive relationships. These include net veining, MMEs, synplutonic dykes, and positive gravity anomalies (Hall 1996); all these are found in the Soukkio Complex. The basal part of the complex is a dynamically layered gabbro, in contact with supracrustal rocks. The following scenario can be then envisaged, although it involves speculation concerning especially the initiation of the process, due to lack of pertinent geochemical and isotopic data from the granite.

Mafic magma was generated from the mantle under a thin, young and immature crust, which was composed mainly of volcanic rocks and pelites but possibly also of older granitoids. After the mafic magma intruded the crust, it began to convect in the magma chamber. When its margins started to crystallize, the magma liberated great amounts of heat to the surrounding crust. Parts of partially crystallized cumulates of the chamber margins collapsed and flowed on the chamber floor as density currents, creating the layered cumulate zone on the bottom of the chamber. A thermal pulse caused by the intrusion partially melted the crust. Melting was assisted by regional amfibolite facies metamorphism, resulting in granitic magma above the mafic chamber.

Convection got started in the felsic chamber because of the mafic heat source below. Magma mixing took place in the interface between the chambers and formed a tonalitic-granodioritic hybrid layer.

New mafic magma pulses in the form of fountain-like injections invaded the silicic chamber, forming synplutonic dykes or sheets and MMEs, which were dispersed throughout the granitic magma by convection. The accumulation of heavier mafic and ultramafic layers on the chamber floor trapped felsic magmas and caused gravitationally 
unstable bimodal layering. The trapped felsic magma interacted with the mafic magma, resulting in crenulated and chilled contacts with flame and load-cast structures. Felsic magma attempted to escape to higher levels due to its lower density and disrupted the mafic magma, which formed mafic pillows.

When the complex was crystallizing, late-magmatic gabbro pegmatoids intruded the cumulates. Later, when the body was already crystallized, mafic dikes and late-orogenic potassium granite $(1.83 \mathrm{Ga})$ intruded the complex and formed pegmatites.

\section{CONCLUSIONS AND IMPLICATIONS}

The presented data suggest mingling and restricted mixing of mafic and silicic magmas in the Soukkio Complex, indicating similar $(1.87 \mathrm{Ga})$ ages for the granite and gabbro. Mixing was mainly mechanical, and magma mingling was probably favored over mixing. This was due to the minor volume of mafic magma compared with felsic magma, high contrasts in viscosity and composition, low injection speed of mafic magma (see Campbell \& Turner 1989, Koyaguchi \& Blake 1991) and/or intrusion in a shallow level (see Hall 1996).

The base of the Soukkio Complex is a layered cumulatic gabbro. Features found in the CentralWestern Zone of the complex suggest interlayering of felsic and mafic magmas. The mafic magma, which injected into the felsic magma chamber, was disrupted forming pillows and dispersed MMEs in the South-Central Zone of the complex. The Eastern Zone represents mafic, felsic and hybrid synplutonic dykes or sheets intruded into flowing granitic crystal mush at different stages.

The structures found in the complex are similar to those found in mafic-silicic layered intrusions (Wiebe 1993a, 1996): many features of the Soukkio Complex resemble those of the Newark Island Layered Intrusion (Wiebe 1987a,b), Cadillac Mountains Complex (Wiebe 1994) and Pleasant Bay Gabbro-Diorite (Wiebe 1993b). Thus, the Soukkio Complex is the first known example of a stratified composite intrusion in Finland. The present interpretation and model thus propose new concepts for the origin of typical features of the Soukkio Complex, which were previously thought to be the result of granitization of gabbro by potassium metasomatism.

The small proportion of potential parental mafic-intermediate magmas and recognizable cumulates relative to the voluminous silicic magmas (Fig 2) argues against pure fractional crystallization models (cf. Nurmi \& Haapala 1986) at Mäntsälä. Existence of gabbro-diorite-granite association, and geochemistry and petrography of layered gabbros indicate that both interaction of contrasting magmas and fractional crystallization may play an important role during formation of maficsilicic complexes (Barbarin 1991, Xu et al. 1999), as shown by the present example.

Occurrence of granitic clasts in supracrustal rocks at Mäntsälä and of granitic enclaves within the mafic pillows of the Soukkio Complex may indicate the presence of older crustal nucleus in the Mäntsälä region.

The evolutionary model of the Soukkio Complex suggested here is in accordance with the view of Lahtinen $(1994,1996)$ on the origin of the 1.88$1.87 \mathrm{Ga}$ Svecofennian magmatism by mafic magmatic underplating, subsequent generation of granitic magma by crustal melting and its interaction with the mafic magma. Structures and textures suggesting mingling and mixing occur widely also elsewhere in the Mäntsälä region and the HMGB (Eerola et al. 2000). This reveals a wide synorogenic zone of coeval felsic and mafic magmatism in southern Finland, with implications for crustmantle interaction and Fe-Ti-P mineralization potential in the Svecofennian orogen (Kärkkäinen \& Appelqvist 1999, Eerola et al. 2000). Due to the widespread evidence of magma mingling and mixing, the Mäntsälä region might be one of the key areas in studies on synorogenic mafic-felsic magma interaction and crust-mantle relationship in the Svecofennian orogen in Finland (Lahtinen 2000).

Magma mingling and mixing were probably more common during the Svecofennian Orogeny than what has been previously thought. Therefore the occurrences of "granitization of gabbro", so 
common in maps of the Finnish Precambrian bedrock, should be reviewed and reinterpreted.

ACKNOWLEDGEMENTS. This paper is a part of the Hyvinkää-Mäntsälä Exploration Project reporting. The project was financed by the Ministry of Trade and Industry of Finland during the years 1997-2000, made in cooperation with the GTK, and coordinated by Prof. R. Törnroos (University of Helsinki). The author thanks the W. Ramsay's and ThG Sahama's Memorial Fund and the Ella and Georg Ehrnroot Fund. Thanks are also due to the Department of Geology and Mineralogy of the University of Helsinki, to GTK's laboratory staff and its Director General, R. Matikainen for cooperation, support, and geochemical analyses. A visit of Prof. R. Vernon to the area in 1999 was stimulating and ideas of the author were confirmed, complemented, and refined by his comments. Discussions with Prof. I. Haapala, Drs. R. Lahtinen, R. Raitala, P. Peltonen, V. Suominen, and T. Rämö were very fruitful. Criticism and comments by R. Vernon, N. Kärkkäinen, M. Nironen, and $H$. Mäkitie greatly improved the first versions of the manuscript. Final version was benefited by reviews by Drs. R. Wiebe and O. Eklund and by careful editorial work of Dr. Y. Kähkönen. M. Ajlani drew the maps, Dr. Juhani Ojala checked the English of the manuscript and students J. Bergström and H. Lallukka assisted the fieldwork in 1997. This study is a contribution to IGCP-426 "Granite Systems and Proterozoic Lithospheric Processes”.

\section{REFERENCES}

Andersson, U.B. 1991. Granitoid episodes and mafic-felsic magma interaction in the Svecofennian of the Fennoscandian Shield, with main emphasis on the $\sim 1.8 \mathrm{Ga}$ plutonics. Precambrian Research 51, 127-149.

Ayrton, S.N. 1991. Appinites, lamprophyres and mafic microgranular enclaves: Three related products of interaction between acid and basic magmas. In: Didier, J. \& Barbarin, B. (eds.) Enclaves and Granite Petrology. Developments in Petrology 13. Amsterdam: Elsevier, 465476.

Barbarin, B. 1988. Field evidence for successive mixing and mingling between the Piolard Diorite and the SaintJulien-la-Vêtre Monzogranite (Nord-forez, Massif Cen- tral, France). Canadian Journal of Earth Sciences 25, 4959.

Barbarin, B. 1991. Enclaves of the Mesozoic calc-alkaline granitoids of the Sierra Nevada Batholith, California. In: Didier, J. \& Barbarin, B. (eds.) Enclaves and Granite Petrology. Developments in Petrology 13. Amsterdam: Elsevier, 135-153.

Bergantz, G.W. 2000. On the dynamics of magma mixing by reintrusion: implications for pluton assembly processes. Journal of Structural Geology 22, 1297-1309.

Blake, D.H., Elwell, R.W.D., Gibson, I.L., Skelhorn, R.S. \& Walker, G.P.L. 1965. Some relationships resulting from the intimate association of acid and basic magmas. Quarterly Journal of the Geological Society of London 121, 31-49.

Bussell, M.A. 1991. Enclaves in the Mesozoic and Cenozoic granitoids of the Peruvian Coastal Batholith. In: Didier, J. \& Barbarin, B. (eds.) Enclaves and Granite Petrology. Developments in Petrology 13. Amsterdam: Elsevier, 155-166.

Bussy, F. 1990. The rapakivi texture of feldspars in a plutonic mixing environment: a dissolution-recrystallization process? Geological Journal 25, 319-324.

Campbell, I.H. \& Turner, J.S. 1989. Fountains in magma chambers. Journal of Petrology 30, 885-923.

Didier, J. 1973. Granites and their Enclaves. Amsterdam: Elsevier. 393 p.

Didier, J. \& Barbarin, B. 1991a. Enclaves and Granite Petrology. Developments in Petrology 13. Amsterdam: Elsevier. 625 p.

Didier, J. \& Barbarin, B. 1991b. The different types of enclaves in granites - nomenclature. In: Didier, J. \& Barbarin, B. (eds.) Enclaves and Granite Petrology. Developments in Petrology 13. Amsterdam: Elsevier, 19-23.

Dobnikar, M., Dolenec, T., Fioretti, A.M. \& Bellini, G. 2000. The origin of plagioclase-mantled K-feldspar in porphyry rocks of Karavanke Granitic Massif (Slovenia). In: Lukkari, S. \& Haapala, I. (eds.) Rapakivi granites and associated mineralization. IGCP Project 373 Field Conference in southern Finland, July 3-7, 2000. Excursion Guide and Abstracts, 36-37.

Eerola, T. 2000. Research and exploration on mafic-ultramafic intrusions in the Mäntsälä region 1997-1999 - Final Report (in Finnish, with English summary). Unpublished report, Hyvinkää-Mäntsälä Exploration Project, Department of Geology and Mineralogy, University of Helsinki. 44 p.

Eerola, T. \& Ajlani, M. 2000. GIS-based research data on the Svecofennian mafic-ultramafic intrusions in Mäntsälä area, southern Finland. Geological Survey of Finland, Open File Archive M19/2044/-00/1. 4 p. + maps + CD ROM.

Eerola, T. \& Haapala, I. 2000. Mingling in the Paleoproterozoic Soukkio Complex in Mäntsälä, southern Finland. $31^{\text {st }}$ International Geological Congress, Rio de Janeiro, Brazil, 06.08.-17.08.2000, Abstract Volume CD-Rom.

Eerola, T., Raitala, R., Bergström, J., Eloranta, T., Kärkkäinen, N. \& Törnroos, R. 2000. Extensive zone of mafic-felsic magma interaction in the Svecofennian: the 
Hyvinkää-Mäntsälä Gabbroic Belt, Southern Finland. In: Pesonen, L., Korja, A.K. \& Hjelt, S-E. (eds.) Lithosphere 2000 - A Symposium on the Structure, Composition and Evolution of the Lithosphere in Finland. Programme and Extended Abstracts, Espoo, Finland, October 3-4, 2000. Institute of Seismology, University of Helsinki, Report S-41, 185-192.

Eerola, T. \& Törnroos, R. 2000. Magma mingling in the Svecofennian layered Gabbro-Granite Complex of Soukkio in Mäntsälä (in Finnish, with English summary). Geologi 52, 132-140.

Ehlers, C. \& Lindroos, A. 1990. Early Proterozoic Svecofennian volcanism and associated plutonism in Enklinge, SW Finland. Precambrian Research 47, 307-318.

Ehlers, C., Lindroos, A. \& Selonen, O. 1993. The late Svecofennian granite-migmatite zone of southern Finland - a belt of transpressive deformation and granite emplacement. Precambrian Research 64, 295-309.

Eklund, O., Konopelko, D., Rutanen, H., Fröjdö, S. \& Shebanov, A.D. 1998. 1.8 Ga Svecofennian post-collisional shoshonitic magmatism in the Fennoscandian shield. Lithos 45, 87-108.

Eklund, O. \& Shebanov, A.D. 1999. The origin of rapakivi texture by sub-isothermal decompression. Precambrian Research 95, 129-146.

Hakkarainen, G. 1994. Geology and geochemistry of the Hämeenlinna-Somero Volcanic Belt, Southwestern Finland: A Paleoproterozoic island arc. In: Nironen, M. \& Kähkönen, Y. (eds.) Geochemistry of Proterozoic supracrustal rocks in Finland. Geological Survey of Finland, Special Paper 19, 85-100.

Hall, A. 1996. Igneous Petrology. $2^{\text {nd }}$ ed. London, Longman. 551 p.

Härme, M. 1958. Examples of the granitisation of plutonic rocks. Bulletin de la Commision Geológique de Finlande 180, 45-64.

Härme, M. 1978. Keravan ja Riihimäen kartta-alueiden kallioperä. Summary: Pre-Quaternary rocks of the Kerava and Riihimäki map-sheet areas. Geological map of Finland 1: 100 000, Explanation to the maps of PreQuaternary rocks, Sheets 2043 and 2044. Geological Survey of Finland. $51 \mathrm{~s}$.

Hibbard, M.J. 1981. The magma mixing origin of mantled feldspars. Contributions to Mineralogy and Petrology 76, $148-170$.

Hildreth, W. 1981. Gradients in silicic magma chambers: implications for lithospheric magmatism. Journal of Geophysical Research 86, 10153-10192.

Huppert, H.E. \& Sparks, R.S. 1988. The generation of granitic magmas by intrusion of basalt into continental crust. Journal of Petrology 29, 599-624.

Huhma, H. 1986. Sm-Nd, U-Pb and Pb-Pb isotopic evidence for the origin of the early Proterozoic Svecokarelian crust in Finland. Geological Survey of Finland, Bulletin 337. 48 p.

Irvine, T.N. \& Baragar, W.R.A. 1971. A guide to the chemical classification of the common volcanic rocks. Canadian Journal of Earth Sciences 8, 523-548.
Kähkönen, Y., Lahtinen, R. \& Nironen, M. 1994. Paleoproterozoic supracrustal belts in southwestern Finland. In: Pajunen, M. (ed.) High temperature-low pressure metamorphism and deep crustal structures. Meeting of IGCP project "Deep Crustal Processes" in Finland, September 16-20, 1994. Geological Survey of Finland, Guide 37, 43-47.

Kaitaro, S. 1956. Riihimäki. Geological map of Finland $1: 100$ 000, Pre-Quaternary rocks, Sheet 2044. Geological Survey of Finland.

Kananoja, T. \& Grönholm, S. 1993. Uudenmaan kallioperän suojelu- ja opetuskohteita. Ympäristöministeriön alueidenkäytönosaston tutkimusraportti 3. 248 p. (In Finnish)

Kärkkäinen, N. \& Appelqvist, H. 1999. Genesis of a lowgrade apatite-ilmenite-magnetite deposit in the Kauhajärvi gabbro, western Finland. Mineralium Deposita 34, 754-769.

Koistinen, T. (ed.) 1994. Precambrian basement of the Gulf of Finland and surrounding area, 1:1 mill. Geological Survey of Finland, Espoo.

Koyaguchi, T. \& Blake, S. 1991. Origin of mafic enclaves: constraints on the magma mixing model from fluid dynamic experiments. In: Didier, J. \& Barbarin, B. (eds.) Enclaves and Granite Petrology. Elsevier: Amsterdam, 415-429.

Krauskopf, K.B. 1982 Introduction to Geochemistry. $2^{\text {nd }}$ ed. Singapore: McGraw-Hill. 617 p.

Lahtinen, R. 1994. Crustal evolution of the Svecofennian and Karelian domains during 2.1-1.79 Ga, with special emphasis on the geochemistry and origin of 1.93-1.91 $\mathrm{Ga}$ gneissic tonalites and associated supracrustal rocks in the Rautalampi area, central Finland. Geological Survey of Finland, Bulletin 378. 128 p.

Lahtinen, R. 1996. Geochemistry of Paleoproterozoic supracrustal and plutonic rocks in the Tampere-Hämeenlinna area, southern Finland. Geological Survey of Finland, Bulletin 389. 113 p.

Lahtinen, R. 2000. Summary of the crustal studies. Oral presentation given on 5.10.2000 at Lithosphere $2000 \mathrm{~A}$ symposium on the structure, composition and evolution of the lithosphere in Finland, Geological Survey of Finland, Espoo, Otaniemi, Finland.

Larsen, R.B. \& Brooks, C.K. 1994. Origin and evolution of gabbroic pegmatites in the Skaergaard Intrusion, East Greenland. Journal of Petrology 35, 1654-1679.

Lindberg, B. \& Eklund, O. 1988. Interactions between basaltic and granitic magmas in a Svecofennian postorogenic granitoid intrusion, Åland, southwest Finland. Lithos 22, 13-23.

Lindberg, B. \& Eklund, O. 1992. Mixing between basaltic and granitic magmas in a rapakivi related quartz-feldspar porphyry, Åland, SW Finland. Geologiska Föreningens i Stcokholm Förhandlingar 114, 103-112.

Lowell, G.R. \& Young, G.J. 1999. Interaction between coeval mafic and felsic melts in the St. Francois Terrane of Missouri, USA. Precambrian Research 95, 69-88. 
McBirney, A.R. \& Nicolas, A. 1997. The Skaergaard Layered Series. Part II. Magmatic flow and dynamic layering. Journal of Petrology 38, 569-580.

Mellqvist, C. 1999. Sequential injections of mafic magma into a crystallizing magma chamber - a case study from the Luleå area, northern Sweden. Geologiska Föreningens i Stockholm Förhandlingar 121, 43-48.

Michael, P.J. 1991. Intrusion of basaltic magma into crystallizing granitic magma chamber: The Cordillera del Paine in Southern Chile. Contributions to Mineralogy and Petrology 108, 396-418.

Middlemost, E.A.K. 1994. Naming materials in the magma/igneous rock system. Earth Science Reviews 37, 215-224.

Nakamura, N.1974. Determination of REE, Ba, Fe, Mg, Na and $\mathrm{K}$ in carbonaceous and ordinary chondrites. Geochimica et Cosmochimica Acta 38, 757-775.

Nardi, L.V.S. \& Lima, E.F. 2000. Hybridisation of microgranular enclaves in the Lavras Granite Complex, southern Brazil. Journal of South American Earth Sciences 13, 67-78.

Neves, S.P. \& Vauchez, A. 1995. Successive mixing and mingling of magmas in a plutonic complex of Northeast Brazil. Lithos 34, 275-299.

Nironen, M. 1989. Emplacement and structural setting of granitoids in the early Proterozoic Tampere and Savo Schist Belts, Finland - implications for contrasting crustal evolution. Geological Survey of Finland, Bulletin 346. $83 \mathrm{p}$.

Nironen, M. \& Bateman, R. 1989. Petrogenesis and syntectonic emplacement in the early Proterozoic of southcentral Finland: a reversely zoned diorite-granodiorite and a granite. Geologische Rundschau 78, 617-631.

Nironen, M., Elliott, B.A. \& Rämö, T. 2000. 1.88-1.87 Ga post-kinematic intrusions of the Central Finland Granitoid Complex: a shift from C-type to A-type magmatism during lithospheric convergence. Lithos 53, 37-58.

Nurmi, P. \& Haapala, I. 1987. The Proterozoic granitoids of Finland: granite types, metallogeny and relations to crustal evolution. Bulletin of the Geological Society of Finland 58, 203-233.

Pääjärvi, A. 2000. Rautalammin ja Karttulan kartta-alueiden kallioperä. Summary: Pre-Quaternary rocks of the Rautalampi and Karttula map-sheet areas. Geological map of Finland 1 : 100 000, Explanation to the maps of Pre-Quaternary rocks, Sheets 3223 and 3224. Geological Survey of Finland. 81 p.

Patchett, J. \& Kouvo, O. 1986. Origin of continental crust of 1.9-1.7 Ga age. $\mathrm{Nd}$ isotopes and $\mathrm{U}-\mathrm{Pb}$ zircon in the Svecokarelian terrain of South Finland. Contributions to Mineralogy and Petrology 87, 311-318.

Pearce, J.A. 1983. The role of subcontinental lithosphere in magma genesis at destructive plate margins. In: Hawkesworth, C.J. \& Norry, M.J. (eds.) Continental Basalts and Mantle Xenoliths. Nantwich: Shiva, 230249.

Pearce, J.A. 1996. Sources and settings of granitic rocks. Episodes 19, 120-125.
Pearce, J.A. \& Cann, J.R. 1973. Tectonic setting of basic volcanic rocks determined using trace element analyses. Earth and Planetary Science Letters 19, 290-300.

Pearce, J.A., Harris, N.BW. \& Tindle, A.G. 1984. Trace element discrimination diagrams for the tectonic interpretation of granitic rocks. Journal of Petrology 25, 956983.

Pearce, T.H., Gorman, B.E. \& Birkett, T.C. 1977. The relationship between major element chemistry and tectonic environment of basic and intermediate volcanic rocks. Earth and Planetary Science Letters 36, 121-132.

Pitcher, W.S. 1991. Synplutonic dykes and mafic enclaves. In: Didier, J. \& Barbarin, B. (eds.) Enclaves and Granite Petrology. Developments in Petrology 13. Amsterdam: Elsevier, 383-391.

Pitcher, W.S. 1993. The Nature and Origin of Granite. Cornwall: Blackie Academic and Professional. 321 p.

Preston, R.J. 2001. Composite minor intrusions as windows into subvolcanic magma reservoir processes: mineralogical and geochemical evidence for complex magmatic plumbing systems in the British Tertiary Igneous Province. Journal of the Geological Society of London 158, 47-58.

Raitala, R., Eerola, T., Törnroos, R., Kärkkäinen, N., Tiainen, M. \& Valli, T. 2000. The Paleoproterozoic Hyvinkää-Mäntsälä Gabbroic Belt. $31^{\text {st }}$ International Geological Congress, Rio de Janeiro, Brazil, 06.08.17.08.2000, Abstract Volume Cd-rom.

Rämö, O.T., Nironen, M., Kosunen, P. \& Elliott, B.A. 1999. Proterozoic granites of South- central Finland Traverse across a Paleoproterozoic terrane boundary. IGCP Project 426 Field Trip to Southern and Central Finland, September 13-18, 1999, Field Trip Guide. 106 p.

Rautiainen, J. 2000. Arkeeisen kratonin reunalla esiintyvät intermediääriset juonet Iisalmen, Juankosken ja Siilinjärven alueilla. Unpublished master's thesis, University of Helsinki, Department of Geology and Mineralogy. 60 p. (in Finnish).

Salonsaari, P. 1995. Hybridization in the subvolcanic Jaala-Iitti Complex and its petrogenetic relation to rapakivi granites and associated mafic rocks of southeastern Finland. Bulletin of the Geological Society of Finland 67. $104 \mathrm{p}$.

Semenov, V., Klepinin, S., Koltsov, A. \& Semenov, S. 2000. The origin of fine-grained rocks and PGE mineralization in the Lukkulaisvaara Layered Intrusion (Northern Karelia, Russia). In: Kojonen, K., Carlson, L., Hölttä, P. \& Lahti, S. (eds.) Extended Abstracts, MSF Mini-Symposium. Geological Survey of Finland, Guide 48, 75-79.

Snyder, D. \& Tait, S. 1995. Replenishment of magma chambers: comparison of fluid mechanic experiments with field relations. Contributions to Mineralogy and Petrology 122, 230-240.

Sylvester, A.G. 1998. Magma mixing, structure and reevaluation of the emplacement mechanism of Vrådal pluton, central Telemark, southern Norway. Norsk Geologisk Tidsskrift 78, 259-276. 
Tiainen, M. \& Viita, H. 1994. Determination of ore potential areas in the Häme Belt, southwestern Finland, by integration of geological, gephysical and till geochemical data. Geological Survey of Finland, Report of Investigation 125.49 p.

Tuttle, O.F. \& Bowen, N.L. 1958. Origin of granite in the light of experimental studies in the system $\mathrm{NaAlSi}_{3} \mathrm{O}_{8}-$ $\mathrm{KAlSi}_{3} \mathrm{O}_{8}-\mathrm{SiO}_{2}-\mathrm{H}_{2} \mathrm{O}$. Geological Society of America Memoir 74. 153 p.

Väisänen, M., Mänttäri, I., Kriegsman, L.M. \& Hölttä, P. 2000. Tectonic setting of post- collisional magmatism in the Paleoproterozoic Svecofennian Orogen, SW Finland. Lithos 54, 63-81.

Vernon, R. 1983. Restite, xenoliths and microgranitoid enclaves in granites. Journal of Proceedings of the Royal Society of New South Wales 116, 411-423.

Vernon, R.H. 1984. Microgranitoid enclaves in granites globules of hybrid magma quenched in a plutonic environment. Nature 309, 438-439.

Vernon, R.H. 1986. K-feldspar megacrysts in granites phenocrysts, not porphyroblasts. Earth Science Reviews $23,1-63$.

Vernon, R.H. 1996. Observation versus argument by authority - the origin of enclaves in granites. Journal of Geoscience Education 44, 57-64.

Vernon, R.H., Etheridge, M.A. \& Wall, V.J. 1988. Shape and microstructure of microgranitoid enclaves: indicators of magma mingling and flow. Lithos 22, 1-11.

Wager, L.R. \& Brown, G.M. 1967. Layered Igneous Rocks. London: Oliver and Boyd. 588 p.

Weinberg, R.F. 1997. The disruption of a diorite magma pool by intruding granite: The Sobu body, Ladakh Batholith, Indian Himalayas. Journal of Geology 105, 87-98.

Wiebe, R.A. 1987a. Evidence for stratification of basic, silicic and hybrid magmas in the Newark Island layered intrusion, Nain, Labrador. Geology 15, 349-352.
Wiebe, R.A. 1987b. Rupture and inflation of a basic magma chamber by silicic liquid. Nature $326,69-72$

Wiebe, R. 1991. Commingling of contrasted magmas and generation of mafic enclaves in granitic rocks. In: Didier, J. \& Barbarin, B. (eds.) Enclaves and Granite Petrology. Developments in Petrology 13. Amsterdam: Elsevier, 393-402.

Wiebe, R.A. 1993a. Basaltic injections into floored silicic magma chambers. EOS 74, 1-3.

Wiebe, R.A. 1993b. The Pleasant Bay Layered GabbroDiorite, Coastal Maine: Ponding and crystallization of basaltic injections into silicic magma chamber. Journal of Petrology 34, 461-489.

Wiebe, R.A. 1994. Silicic magma chambers as traps for basaltic magmas: The Cadillac Mountain Complex, Mount Desert Island, Maine. Journal of Geology 102, 423-437.

Wiebe, R.A. 1996. Mafic-silicic layered intrusions: the role of basaltic injections on magmatic processes and the evolution of silicic magma chambers. Transactions of the Royal Society of New South Wales 116, 99-124.

Wiebe, R. \& Snyder, D. 1993. Slow, dense replenishments of a basic magma chamber: the layered series of the $\mathrm{Ne}$ wark Island layered intrusion, Nain, Labrador. Contributions to Mineralogy and Petrology 113, 59-72.

Wiebe, R.A. \& Collins, W.J. 1998. Depositional features and stratigraphic sections in granitic plutons: implications for the emplacement and crystallization of granitic magma. Journal of Structural Geology 20, 1273-1289.

Xu, X., Dong, C., Li, W. \& Zhou, X. 1999. Late Mesozoic intrusive complexes in the coastal area of Fujian, SE China: the significance of the gabbro-diorite-granite association. Lithos 46, 299-315. 